\title{
Autoradiographic Localization and Characterization of Tachykinin Receptor Binding Sites in the Rat Brain and Peripheral Tissues
}

\author{
Patrick W. Mantyh, ${ }^{1-3}$ Troy Gates, ${ }^{1}$ Christopher R. Mantyh, ${ }^{1}$ and John E. Maggio ${ }^{4}$ \\ ${ }^{1}$ Center for Ulcer Research and Education, VA Medical Center-Wadsworth, Los Angeles, California 90073, ${ }^{2}$ Brain \\ Research Institute and ${ }^{3}$ Department of Medicine, UCLA School of Medicine, Los Angeles, California 90024, and \\ ${ }^{4}$ Department of Biological Chemistry and Molecular Pharmacology, Harvard Medical School, Boston, Massachusetts \\ 02115
}

Quantitative receptor autoradiography using several radiolabeled tachykinins was used to localize and characterize tachykinin peptide receptor binding sites in rat CNS and peripheral tissues. Autoradiographic localization and displacement experiments using several radiolabeled tachykinins indicate that in the rat there are at least 3 distinct tachykinin receptor binding sites. One of these is present iri both the CNS and peripheral tissues, one is present only in the CNS, and one is present only in peripheral tissues.

The first tachykinin receptor binding site, which is detectable in both the CNS and peripheral tissues, appears to prefer substance $P(\mathrm{SP})$ as an endogenous ligand. Areas expressing high concentrations of this binding site include the medial septum, superior colliculus, inferior olive, inner plexiform layer of the retina, external muscle of the bladder, and the muscularis externa of the esophagus.

The second type of tachykinin receptor binding site, which is detectable only in the CNS appears to prefer either neuromedin $K(N K)$ and/or substance $K$ (SK) as the endogenous ligand. This receptor binding site is labeled by Bolton-Hunter conjugates of NK, SK, eledoisin, or kassinin and is found in high concentrations in laminae 4 and 5 of the cerebral cortex, the ventral tegmental area, laminae 1 and 2 of the spinal cord, and the inner plexiform layer of the retina.

The third type of tachykinin receptor binding site is detectable only in peripheral tissues and appears to prefer SK as the endogenous ligand. This receptor binding site is labeled by SK, eledoisin, or kassinin radioligands and tissues that express high concentrations include the muscularis mucosae of the esophagus, the circular muscle of the colon, and the external muscle of the bladder.

These data suggest that SP receptors are expressed in the brain and peripheral tissues, NK receptors are expressed in the CNS, and SK receptors are expressed in peripheral tissue. These data fit well with radioimmunoassay data that suggest that, whereas in the CNS SP, SK and NK are present in high concentrations, in peripheral tissues only SP and SK are present in detectable concentrations. The present clas-

Received Feb. 23, 1988; revised May 10, 1988; accepted May 20, 1988.

This work was supported by the Amyotrophic Lateral Sclerosis Association, Southern California Arthritis Foundation, American Heart Association, Los Angeles Chapter, Smith Kline and Beckman Fellowship, Alfred Sloan Fellowship, and NS-22961 and NS-23970.

Correspondence should be addressed to Dr. Patrick W. Mantyh, CURE/UCLA, VA Wadsworth, Bldg. 115, Rm. 220, Los Angeles, CA 90073.

Copyright (C) 1989 Society for Neuroscience $0270-6474 / 89 / 010258-22 \$ 02.00 / 0$ sification of tachykinin receptors places a lower limit on the number of mammalian tachykinin receptor types and provides a functional/morphological framework for exploring the diverse actions of tachykinin peptides in both the CNS and peripheral tissues.

The mammalian tachykinin family is currently known to be composed of 3 neuropeptides: substance $P(\mathrm{SP})$, substance $K$ (SK; neurokinin A, alpha-neurokinin, neuromedin L), and neuromedin K (NK; neurokinin B, beta-neurokinin). Since tachykinins are a family of peptides with the common carboxylterminal amino acid sequence -Phe-X-Gly-Leu-Met- $\mathrm{NH}_{2}$ (Espamer, 1981; Maggio, 1988) (Table 1), it is important to know whether all of the tachykinins interact with a single receptor or whether each tachykinin utilizes its own specific receptor binding site. Previous studies are equivocal on this point as some studies suggest that the known mammalian tachykinins interact with a single tachykinin receptor binding site in peripheral tissues (Souquet et al., 1985), while other studies suggest that there are at least 2 distinct tachykinin receptor binding sites in peripheral tissues (Burcher et al., 1984, 1986; Mantyh et al., 1984d, 1987, 1988a, b; Buck and Burcher, 1985; Maggio et al., 1985).

Demonstration that pharmacologically relevant receptor binding sites are present on specific cell types is critical for assessing tachykinin action in the brain and peripheral tissues since it is believed that all tachykinin actions described to date are receptor-mediated (Pernow, 1983; Bartho and Holzer, 1985; Maggio, 1988). Demonstration of tachykinin receptor binding sites is also important since it is hypothesized that the presence of a particular neurotransmitter in a nerve does not necessarily imply that that particular neurotransmitter has a functional action on the innervated cell type (Dale, 1935; Eccles, 1957). While many neurons are known to contain multiple neurotransmitters, it has not been demonstrated that neurons are able to ship particular ncurotransmitters only to those branches that innervate cells with postsynaptic receptors for that transmitter. This point is particularly germane to the tachykinins since the density of SP innervation and the density of SP binding sites do not correlate across CNS regions (Mantyh et al., 1984b, c, e; Schults et al., 1984). Furthermore, cloning of the bovine (Nawa et al., 1983, 1984), human (Harmar et al., 1986; Bonner et al., 1987), and rat (Bonner et al., 1987; Krause et al., 1987) cDNAs has revealed 4 tachykinin precursor proteins encoded by 2 genes. The first gene encodes for SP and SK and gives rise to 3 precursors. Two of these precursors, beta- and gamma-preprotachykinin A (or I), contain one copy each of SP and SK, while 
Table 1. Structure of tachykinins

\begin{tabular}{|c|c|}
\hline Tachykinin & Structure \\
\hline Substance $\mathrm{P}$ & H-Arg-Pro-Lys-Pro-Gln-Gln-Phe-Phe-Gly-Leu-Met-NH \\
\hline Substance K & H-His-Lys-Thr-Asp-Ser-Phe-Val-Gly-Leu-Met- $-\mathrm{NH}_{2}$ \\
\hline Neuromedin $\mathrm{K}$ & H-Asp-Met-His-Asp-Phe-Phe-Val-Gly-Leu-Met- $-\mathrm{NH}_{2}$ \\
\hline Eleduisin & pGlu-Pro-Ser-Lys-Lys-Asp-Ala-Phe-Ile- $\overline{\text { Gly }}-\overline{\text { Leu }}-\overline{\mathrm{Met}}-\mathrm{NH}_{2}$ \\
\hline Kassinin & H-Asp-Val-Pro-Lys-Ser-Asp-Gln-Phe-Val-Gly-Leu-Met-NH \\
\hline $\begin{array}{l}\text { Common tachykinin } \\
\text { sequence }\end{array}$ & -Phe-X-Gly-Leu-Met-NH \\
\hline
\end{tabular}

Sequence homologies are indicaled by underlining. Mammalian tachykinins begin with a capital letter. Neurokinin- $u$, neurokinin $\mathrm{A}$, and neuromedin $\mathrm{L}$ are alternative names for substance $\mathrm{K}$. Neurokinin- $\beta$, neurokinin $\mathrm{B}$ are alternative names for neuromedin $\mathrm{K}$. $\mathrm{H}$ - denotes a free amino terminus, $-\mathrm{NH}_{2}$ a carboxyl terminal carboxyamide, and pGlu a pyroglutamic acid moiety.

the other precursor, alpha-preprotachykinin A, contains a single copy of SP. The second gene encodes preprotachykinin B (or II), a precursor for NK only; the mRN $\Lambda$ for $\mathrm{NK}$ has been reported to be present in the bovine brain and small and large intestine (Kotani et al., 1986). Radioimmunoassay data is in general agreement with the molecular genetics data in that SP and SK coexist in most areas of the brain and periphery and appear to be co-released in all systems examined to date (Kanazawa et al., 1984; Maggio and Hunter, 1984; Deacon et al., 1987). NK, on the other hand, appears to be expressed in a different pattern than SP and SK in the brain and has not been detected in peripheral tissues and sensory ganglia in the rat (Minamino et al., 1984; Ogawa et al., 1985; Deacon et al., 1987).

In the present report we have used quantitative receptor autoradiography to explore the characteristics and distribution of tachykinin receptors in the rat brain and peripheral tissues. To accomplish this we have tested 19 different radioligands on rat brain and peripheral tissues and from these 19 radioligands report in detail on 5 that consistently gave good resolution with high specific/nonspecific binding ratios. Thus, we have used radiolabeled analogs of the 3 mammalian tachykinins (substance $P$, substance $K$, and neuromedin $K$ ) and 2 nonmammalian tachykinins (kassinin and eledoisin) that have been used extensively in previous physiological and pharmacological experiments to demonstrate the existence of multiple tachykinin receptors.

\section{Materials and Methods}

In the present study, several tachykinin radioligands were tested for suitability in autoradiographic studies. These radioligands, their abbreviations, and origin are listed in Table 2 below. Complete peptide sequences are given in Table 1 . The radioligands synthesized in our laboratory were prepared from commercially available peptide precursors and reagents by conventional radioiodination techniques (IIunter and Greenwood, 1962; Bolton and Hunter, 1973; Cascieri and Liang, 1984). Following synthesis, the radioiodinated peptides were purified by reverse-phase HPLC to essentially quantitative specific activity $(2000 \mathrm{Ci} /$ $\mathrm{mmol}$, diluted to less than $10^{8} \mathrm{dpm} / \mathrm{ml}$, and stored at $-20^{\circ} \mathrm{C}$ in solutions containing $0.2 \% 2$-mercaptoethanol as antioxidant. Under these conditions, the monoiodinated radioligands were stable for at least 3 months, and the diiodinated ligands for at least 1 month. The radioligand stock solutions were diluted to a working concentration of $100 \mathrm{pm}$ shortly before incubation with tissue sections. Except as noted, all peptides were from Bachem, all radioisotopes from Amersham, and all chemicals and biochemicals from Sigma.

Rats were sacrificed by decapitation and tissues rapidly dissected out. Tissues were then blocked, placed on a brass microtome chuck, and frozen on dry ice. The tissues were then serially sectioned $(30 \mu \mathrm{m})$, thawmounted onto gelatin-coated microscope slides, and stored at $-20^{\circ} \mathrm{C}$ over desiccant for up to 3 months.
For autoradiography with the BHSP (radioligand 3 in Table 1), the slide-mounted tissue sections were brought to room temperature and placed in a preincubation medium $(50 \mathrm{~mm}$ Tris- $\mathrm{HCl}, \mathrm{pH} 7.4$, containing $0.005 \%$, vol/vol, polyethylenimine) at $19^{\circ} \mathrm{C}$ for $10 \mathrm{~min}$ before incubation with radioligand. The sections were then incubated at $19^{\circ} \mathrm{C}$ for $1 \mathrm{hr}$ in a solution of $100 \mathrm{pm}$ BHSP in $50 \mathrm{~mm}$ Tris- $\mathrm{HCl}, \mathrm{pH} 7.4$, containing $\mathrm{MnCl}_{2}$ (3 mM), BSA (200 mg/liter), chymostatin (2 mg/liter), leupeptin ( $4 \mathrm{mg} /$ liter), and bacitracin $(40 \mathrm{mg} / \mathrm{liter})$. To conserve radioligand, the incubation was accomplished by placing the slides on a horizontal surface and covering the sections with the incubation medium. HPLC analysis confirmed that under these conditions, no significant degradation or oxidation of radioligand is observed during the course of the experiments. To estimate nonspecific binding, paired serial sections were incubated as described except that $1 \mu \mathrm{M}$ SP was present in the incubation solution. Following incubation with radioligand, slides were rinsed twice in $50 \mathrm{~mm}$ Tris- $\mathrm{HCl}, \mathrm{pH} 7.4\left(4^{\circ} \mathrm{C}, 2 \mathrm{~min}\right.$ each), then 4 times in distilled water $\left(4^{\circ} \mathrm{C}, 5 \mathrm{scc}\right.$ cach), and then quickly dried in the cold room using a stream of cold air. After $3 \mathrm{hr}$ further drying at $4^{\circ} \mathrm{C}$, sections were stored over desiccant at room temperature overnight before autoradiography. The same procedure was used for the $\mathrm{I}_{2}$-BHSP (radioligand 4); the doubly iodinated ligand consistently gave a lower specific/ nonspecific binding ratio than the mono-iodo derivative. The tritiated ligands ${ }^{3} \mathrm{H}-\mathrm{SP}$ and ${ }^{3} \mathrm{H}-\mathrm{PrSP}$ (radioligands 1 and 2), being of significantly lower specific activity than the iodinated ligands, were used at a concentration of $2 \mathrm{nM}$; otherwise, the proccdurc was as described above. Controls for chemographic artifacts were performed as above except that radioligand was omitted from the incubation medium.

For the SK and NK radioligands, the same protocol was employed except that polyethylenimine was omitted from the preincubation, the length of the incubation increased to $2 \mathrm{hr}$ and the $\mathrm{pH}$ of the incubation medium was increased to 8.0 for the SK radioligands and 8.5 for the NK radioligands; nonspecific binding was estimated using $1 \mu \mathrm{M} \mathrm{SK}$ or NK. The Bolton-Hunter conjugates of kassinin and eledoisin (ligands 16 and 17 in Table 2) were studied under the conditions used for SK radioligands. the 5 radioligands (numbered $5,9,10,18,19$ in Table 2) which failed to give specific binding under the above protocols were further studied under a variety of other conditions (varying incubation and wash times, $\mathrm{pH}$, salt, and temperature) without success.

For quantitative autoradiographic analysis of tachykinin binding sites, the slide-mounted tissue sections were placed in apposition to tritiumsensitive Ultrofilm (LKB). Radioiodinated brain mash or standards (see below) exposed simultaneously provided the basis for quantitation. After 1-4 weeks exposure, the film was developed in Kodak D-19 developer, fixed, and washed. In those cases where a higher degree of histological resolution was desirable, the same slide-mounted sections were processed for standard emulsion-dipped autoradiography following fixation by formaldehyde vapor (Herkenham and Pert, 1982). After the emulsion-dipped autoradiograms were developed, the sections were placed in Carnoy's fixative for $3 \mathrm{hr}$, stained with hematoxylin and eosin or cresyl violet, and mounted with Histoclad. Dark- and bright-field photomicrographs were then taken of the silver grains and counterstained sections, respectively. Using this approach, 3 complementary images were generated: the film autoradiogram, which was analyzed for quantitative densitometry; the emulsion autoradiogram, which provided detailed histological resolution of binding sites; and the counterstained section, which allowed identification of the cell types expressing the binding sitcs. 


\begin{tabular}{|c|c|c|}
\hline Abbreviation & Radioligand & Notes \\
\hline 1. ${ }^{3} \mathrm{H}-\mathrm{SP}$ & Substance $P,\left[\right.$ prolyl$\left.^{2}-3,4(n)-{ }^{3} \mathrm{H}\right]$ & $a$ \\
\hline 2. ${ }^{3} \mathrm{H}-\mathrm{PrSP}$ & Substance $\mathrm{P},\left[\mathrm{Na}-{ }^{3} \mathrm{H}\right.$-propionyl $]$ & $b$ \\
\hline 3. BHSP & Substance $\mathrm{P},\left[\mathrm{Na}-{ }^{125}\right.$-monoiodo-Bolton-Hunter $]$ & $a-c$ \\
\hline 4. $\mathrm{I}_{2}$-BHSP & Substance $\mathrm{P},\left[\mathrm{Na}-\left({ }^{125} \mathrm{I}_{2}\right)\right.$-diiodo-Bolton-Hunter $]$ & $c$ \\
\hline \multicolumn{3}{|c|}{ Substance $\mathrm{K}$ radioligands } \\
\hline 5. ${ }^{3} \mathrm{H}-\mathrm{PrSK}$ & Substance $\mathrm{K},\left[\mathrm{Na}-{ }^{3} \mathrm{H}\right.$-propionyl] & $b$ \\
\hline 6. BHSK & Substance K, [Na-125I-monoiodo-Bolton-Hunter] & $c$ \\
\hline 7. $\mathrm{I}_{2}$-BHSK & Substance $\mathrm{K},\left[\mathrm{Na}-\left({ }^{125} \mathrm{I}_{2}\right)\right.$-diiodo-Bolton-Hunter $]$ & $c$ \\
\hline 8. ISK & Substance K, [2-125I-iodohistidyl'] & $b, c$ \\
\hline 9. BHSK (4-10) & Substance $\mathrm{K}^{4-10}$ heptapeptide, [Na-125-monoiodo-Bolton-Hunter] & $c$ \\
\hline 10. $T Y^{0}-S K$ & Substance $\mathrm{K},\left[\mathrm{Na}-\left(\mathrm{m}-{ }^{125} \mathrm{~T}\right.\right.$-iodotyrosyl)] & $c$ \\
\hline \multicolumn{3}{|c|}{ Neuromedin $\mathrm{K}$ radioligands } \\
\hline 11. ${ }^{3} \mathrm{H}-\mathrm{PrNK}$ & Neuromedin $\mathrm{K},\left[\mathrm{Na}-{ }^{3} \mathrm{H}\right.$-propionyl] & $b$ \\
\hline 12. BHNK & Neuromedin $\mathrm{K}$, [Na- ${ }^{125}$ I-monoiodo-Bolton-Hunter] & $c$ \\
\hline 13. $\mathrm{I}_{2}-\mathrm{BHNK}$ & Neuromedin $\mathrm{K}$, [Na-( $\left.{ }^{125} \mathrm{I}_{2}\right)$-diiodo-Bolton-Hunter] & $c$ \\
\hline 14. INK & Neuromedin K, $\left[2^{123} \mathrm{I}\right.$-iodohistidyl $\left.\mathrm{l}^{3}\right]$ & $c$ \\
\hline 15. IY ${ }^{0}-\mathrm{NK}$ & Neuromedin $\mathrm{K},\left[\mathrm{Na}-\left(m^{-125}[\right.\right.$-iodotyrosyl $\left.)\right]$ & $c$ \\
\hline \multicolumn{3}{|l|}{ Other radioligands } \\
\hline 16. BHK & Kassinin, [Na-125I-monoiodo-Bolton-Hunter] & $c$ \\
\hline 17. $\mathrm{BHE}$ & Eledoisin, [Ne-12sI-monoiodo-Bolton-Hunter] & $c$ \\
\hline 18. BH-senktide & $\begin{array}{l}{\left[\text { Asp }^{5,6}, \mathrm{MePhe}^{8}\right] \text {-substance } \mathrm{P}^{5-11},\left[\mathrm{Na}^{-125} \text { I-monoiodo- }\right.} \\
\text { Bolton-Hunter] }\end{array}$ & $c$ \\
\hline 19. BHNPK & Neuropeptide $\mathrm{K}$, [Ne-125I-monoiodo-Bolton-Hunter] & $c$ \\
\hline
\end{tabular}

New England Nuclear.

$b$ Amersham.

$c$ Synthesized in our laboratory.

To quantitate the density of radiolabeled tachykinin binding sites, microdensitometry (Rainbow et al., 1984) was performed on the film autoradiograms. The developed film was projected at $20 \times$ on a white horizontal surface and the densities of areas of the projected image measured with a photocell (Sharp BS-5900A silicon blue photodiode) connected to a digital voltmeter (Radioshack). The resolution of this device corresponds to region about $20 \mu \mathrm{m}$ in diameter on the projected sections. Correction for the film's nonlinear response to radioactivity was performed using film exposed to series of radioactive standards and an automatic curve-fitting program (Texas Instruments).

\section{Results}

\section{Radioligands tested}

Radioligands that preferentially bind to $S P$ receptors. Of the 19 radioligands tested, 4 (numbers $1-4$ ) preferentially bind to SP receptors. ${ }^{3} \mathrm{H}-\mathrm{SP}$ has proved to be an extremely good ligand when used with polyethylenimine (PEI) and purified by HPLC immediately before use, since it gives very high $(95 / 5)$ specific/ nonspecific binding ratios. The disadvantage of this ligand is that, like all ${ }^{3} \mathrm{H}$-ligands used for autoradiographic analyses, gray/ white quenching differences must be taken into account (IIerkenham and Sokoloff, 1984). However, if these correction factors are incorporated and tritiated microscales (Amersham) are employed, reliable quantitative autoradiography can be performed. The ${ }^{125}$ I-SP ligands we have tested appear to be very good for labeling SP receptors since they produce high $(95 / 5$, for mono-iodo Bolton-Hunter SP) specific/nonspecific binding ratios and do not have the differential quenching problems of ${ }^{3} \mathrm{H}$-ligands, although their relatively short half-lives make it necessary to generate ncw microscales for cach experiment to properly quantify the results. All 4 of the SP radioligands appear to label a single class of SP receptor which shows little affinity for SK or NK; the $\mathrm{IC}_{50}$ of $\mathrm{SK}$ and $\mathrm{NK}$ in displacing these radioligands is 3 orders higher than that for SP.

Substance K radioligands. Three SK radioligands, mono- and di-iodinated Bolton-Hunter conjugates and the "internally labeled" iodohistidyl derivative (numbers 6, 7, 8 respectively, in Table 2) label binding sites in the brain and peripheral tissues of the rat. Each gives high specific/nonspecific binding ratios, and at least in the periphery appears to preferentially label SK receptors. BHSK (number 6 in Table 2) consistently gave the highest specific/nonspecific binding ratios (95/5) of the ligands tested. Three other SK radioligands, the propionylated and tyrosylated derivatives (numbers 5 and 10 in Table 2) and the Bolton-Hunter conjugate of the carboxyl-terminal heptapeptide (number 9 in Table 2), did not exhibit specific binding in either central or peripheral tissues under the protocols described above nor under a variety of other conditions tested. Bolton-Hunter conjugates of kassinin and eledoisin (numbers 16 and 17 in Table 2) also appear to label SK receptors.

Neuromedin K radioligands. Five radioligands have been synthesized to explore the distribution of NK receptors. All appear to bind to the same site in the CNS; however, the internally labeled iodohistidyl NK (number 14 in Table 2) appears to give the highest specific/nonspecific binding ratios of $80 / 20$ ). BHK and BHE also appear to label NK receptors in the rat brain.

Other tachykinin radioligands. The Bolton-Hunter conjugates of kassinin and eledoisin (ligands 16 and 17 in Table 2) label tachykinin binding sites in both central and peripheral tissues, giving patterns that appear very similar to those of BHSK in the same tissues.

We were unable to demonstrate any specific binding of the Bolton-Hunter derivative of senktide (ligand 18 in Table 2), a 


\section{Table 3. Distribution of tachykinin receptor binding sites}

\begin{tabular}{|c|c|c|c|c|c|}
\hline Tissue & SP & NK & SK & $\mathrm{E}$ & $\mathbf{K}$ \\
\hline \multicolumn{6}{|l|}{ Central nervous system } \\
\hline \multicolumn{6}{|l|}{ Olfactory bulb } \\
\hline External plexiform layer & ++++ & + & + & + & + \\
\hline Internal granule layer & + & + & + & + & + \\
\hline \multicolumn{6}{|l|}{ Cerebral Cortex } \\
\hline \multicolumn{6}{|l|}{ Anterior cingulate } \\
\hline I & + & + & + & + & + \\
\hline II-III & + & - & - & - & - \\
\hline IV-V & - & ++++ & ++++ & ++++ & +++ \\
\hline \multicolumn{6}{|l|}{ Frontal-parietal } \\
\hline I & + & + & + & + & + \\
\hline II-III & + & - & - & - & - \\
\hline IV-V & - & ++++ & ++++ & ++++ & +++ \\
\hline \multicolumn{6}{|l|}{ Temporal } \\
\hline 1 & + & + & + & + & + \\
\hline II-III & + & - & - & - & - \\
\hline IV-V & - & ++++ & ++++ & ++++ & ++++ \\
\hline \multicolumn{6}{|l|}{ Entorhinal } \\
\hline I-III & +++ & + & + & + & + \\
\hline IV-V & + & +++ & +++ & +++ & +++ \\
\hline \multicolumn{6}{|l|}{ Septum } \\
\hline Medial & ++ & - & - & - & - \\
\hline Lateral & ++++ & - & - & - & - \\
\hline Nucleus accumbens & +++ & - & - & - & - \\
\hline Caudate-putamen &,++++ & - & - & - & - \\
\hline Amygdalohippocampal area & ++++ & & & & \\
\hline \multicolumn{6}{|l|}{ Amygdala } \\
\hline Basal lateral nucleus & ++ & +++ & +++ & +++ & +++ \\
\hline Central nucleus & ++ & - & - & - & - \\
\hline Lateral nucleus & + & - & - & - & - \\
\hline Medial nucleus & + & - & - & - & - \\
\hline \multicolumn{6}{|l|}{ Hippocampus } \\
\hline CA3 & ++ & + & + & + & + \\
\hline Dentate gyrus & ++ & + & + & + & + \\
\hline Subiculum & ++++ & - & - & - & - \\
\hline \multicolumn{6}{|l|}{ Dorsal thalamus } \\
\hline Anterior nuclei & ++ & - & - & - & - \\
\hline Lateral geniculate nucleus & - & - & - & - & - \\
\hline Medial geniculate nucleus & + & - & - & - & - \\
\hline \multicolumn{6}{|l|}{ Ventral posterior medial } \\
\hline \multicolumn{6}{|l|}{ Ventral posterior lateral } \\
\hline nucleus & - & - & - & - & - \\
\hline \multicolumn{6}{|l|}{ Hypothalamus } \\
\hline Anterior nucleus & +++ & - & - & - & - \\
\hline Dorsomedial nucleus & + & - & - & - & - \\
\hline Lateral nucleus & + & - & - & - & - \\
\hline Paraventricular nucleus & ++ & ++++ & ++++ & ++++ & ++++ \\
\hline Supraoptic & - & ++++ & ++++ & ++++ & ++++ \\
\hline \multicolumn{6}{|l|}{ Ventral Thalamus } \\
\hline \multicolumn{6}{|l|}{ Ventral lateral geniculate } \\
\hline nucleus & + & - & - & - & - \\
\hline \multicolumn{6}{|l|}{ Epithalamus } \\
\hline \multicolumn{6}{|l|}{ Habenular nucleus } \\
\hline Medial & ++ & + & + & + & + \\
\hline Lateral & + & - & - & - & - \\
\hline $\begin{array}{l}\text { Paraventricular thalamic } \\
\text { nucleus }\end{array}$ & $+t+$ & - & - & - & - \\
\hline
\end{tabular}




\begin{tabular}{|c|c|c|c|c|c|}
\hline Tissue & $\mathrm{SP}$ & NK & SK & $\mathrm{E}$ & $\mathrm{K}$ \\
\hline \multicolumn{6}{|l|}{ Mesencephalon } \\
\hline Interpeduncular nucleus & ++ & ++ & ++ & ++ & ++ \\
\hline \multicolumn{6}{|l|}{ Periaqueductal grey } \\
\hline Dorsal & ++ & + & + & + & + \\
\hline Lateral & ++ & - & + & + & + \\
\hline Medial & $+t$ & + & + & + & + \\
\hline \multicolumn{6}{|l|}{ Substantia nigra } \\
\hline Compacta & + & + & + & + & + \\
\hline Reticulata & - & - & - & - & - \\
\hline \multicolumn{6}{|l|}{ Superior colliculus } \\
\hline Superficial layer & ++++ & + & + & + & + \\
\hline Intermediate layer & +++ & - & - & - & - \\
\hline Deep layer & ++ & - & - & - & - \\
\hline Third nucleus & + & - & - & - & - \\
\hline Ventral tegmental area & - & + & + & + & + \\
\hline \multicolumn{6}{|l|}{ Pons } \\
\hline \multicolumn{6}{|l|}{ Cerebellum granule layer } \\
\hline (9 and 10$)$ & ++ & - & - & - & - \\
\hline Dorsal raphe & +++ & - & - & - & - \\
\hline Fourth nucleus & + & - & - & - & - \\
\hline Inferior colliculus & + & - & - & - & - \\
\hline Locus coeruleus & ++++ & + & + & + & + \\
\hline \multicolumn{6}{|l|}{ Parabrachial nucleus } \\
\hline Medial & ++ & - & - & - & - \\
\hline Lateral & ++++ & - & - & - & - \\
\hline \multicolumn{6}{|l|}{ Medulla } \\
\hline Ambiguous & ++ & - & - & - & - \\
\hline \multicolumn{6}{|c|}{ Dorsal motor nucleus of the } \\
\hline vagus & ++++ & - & - & - & - \\
\hline \multicolumn{6}{|l|}{ Inferior olive } \\
\hline Medial & ++ & - & - & - & - \\
\hline Lateral & ++ & - & - & - & - \\
\hline \multicolumn{6}{|l|}{ Raphe nuclei } \\
\hline Magnus & + & - & - & - & - \\
\hline Pallidus & + & - & - & - & - \\
\hline Obscuris & + & - & - & - & - \\
\hline \multicolumn{6}{|l|}{ Solitary nucleus } \\
\hline Medial & +++ & ++++ & ++++ & ++++ & ++++ \\
\hline Lateral & ++ & +++ & +++ & +++ & ++++ \\
\hline \multicolumn{6}{|l|}{ Trigeminal nucleus } \\
\hline Oralis & + & - & - & - & - \\
\hline Interpolaris & + & - & - & - & - \\
\hline \multicolumn{6}{|l|}{ Caudalis } \\
\hline I-II & ++ & +++ & +++ & +++ & +++ \\
\hline $\mathrm{V}$ & + & - & - & - & - \\
\hline \multicolumn{6}{|l|}{ Spinal cord } \\
\hline \multicolumn{6}{|l|}{ Cervical } \\
\hline DRG & - & - & - & - & - \\
\hline I-II & ++ & ++++ & ++++ & ++++ & ++++ \\
\hline III-IV & - & - & - & - & - \\
\hline $\mathrm{V}$ & + & - & - & - & - \\
\hline VI-IX & $t+$ & - & - & & \\
\hline Area X & +++ & - & - & - & - \\
\hline \multicolumn{6}{|l|}{ Thoracic } \\
\hline DRG & - & - & - & - & - \\
\hline I-II & ++ & ++++ & ++++ & ++++ & ++++ \\
\hline III-IV & - & - & - & - & - \\
\hline V & + & - & - & - & - \\
\hline
\end{tabular}




\begin{tabular}{|c|c|c|c|c|c|}
\hline Tissue & SP & NK & SK & $\mathrm{E}$ & $\mathrm{K}$ \\
\hline VI-IX & ++ & - & - & - & - \\
\hline Area $X$ & ++ & - & - & - & - \\
\hline IML & ++++ & - & - & - & - \\
\hline \multicolumn{6}{|l|}{ Lumbar } \\
\hline DRG & - & - & - & - & - \\
\hline I-II & ++ & $+++t$ & ++++ & ++++ & ++++ \\
\hline III-IV & - & - & - & - & - \\
\hline V & + & - & - & - & - \\
\hline VI-IX & ++ & - & - & - & - \\
\hline Area X & +++ & - & - & - & - \\
\hline \multicolumn{6}{|l|}{ Sacral } \\
\hline DRG & - & - & - & - & - \\
\hline I-II & ++ & ++++ & +++ & ++++ & ++++ \\
\hline III-IV & - & - & - & - & - \\
\hline $\mathrm{V}$ & + & - & - & - & - \\
\hline VI-IX & ++ & - & - & - & - \\
\hline Area $X$ & +++ & - & - & - & - \\
\hline Sacral preganglionic & +++ & - & - & - & - \\
\hline Onuf's & +++ & - & - & - & - \\
\hline Retina (inner plexiform layer) & +++ & ++ & ++ & ++ & ++ \\
\hline \multicolumn{6}{|l|}{ Peripheral tissues } \\
\hline \multicolumn{6}{|l|}{ Esophagus } \\
\hline Muscularis mucosae & ++ & - & ++ & ++ & ++ \\
\hline Muscularis externa & + & - & - & - & - \\
\hline \multicolumn{6}{|l|}{ Colon } \\
\hline Circular muscle & ++++ & - & +++ & +++ & +++ \\
\hline Longitudinal muscle & +++ & - & ++ & + & + \\
\hline \multicolumn{6}{|l|}{ Bladder } \\
\hline Muscularis externa & ++++ & - & ++++ & ++++ & ++++ \\
\hline
\end{tabular}

Serially adjacent frozen brain sections $(30 \mu \mathrm{m})$ were labeled as described in the text with ${ }^{23}$ I-BHSP, ${ }^{12}$ [I-BHNK, ${ }^{12 s}$ IBHSK, ${ }^{22} \mathrm{I}-\mathrm{BHE}$, or ${ }^{125} \mathrm{I}-\mathrm{BHK}$ and opposed to LKB Ultrofilm for $10 \mathrm{~d}$. Densitometric readings for each region were taken as described from at least 5 different animals, averaged and corrected for the nonlinearity of the response of the film using autoradiographic standards (Amersham). Values are expressed as a percentage of maximal binding from each ligand where $(-)$ is undetectable, $(+) 0.1-25.0 \%,(++) 25.1-50.0 \%,(+++) 50.1-75.0 \%,(++++) 75.1-100.0 \%$. The area with the maximal density of BHSP binding sites is the amygdalohippocampal area, whereas for BHNK, BHSK, $\mathrm{BHE}$, and BHK, it is the supraoptic hypothalamic nucleus.

synthetic tachykinin derivative reported (Laufer et al., 1986) to specifically label NK binding sites, in any area of the rat brain or periphery examined. With a mixture of 4 different BoltonHunter derivatives of neuropeptide $\mathrm{K}$ (ligand 19 in Table 2), we were also unable to detect any specific binding in any of the central or peripheral tissues examined. It should be emphasized that these radioligands were tried without success under a variety of binding conditions, and the tissues that showed no specific binding of these 2 ligands were shown in parallel experiments done the same day to cxhibit specific binding for the other tachykinin radioligands.

\section{Competitive inhibition of ${ }^{125} I$-Bolton-Hunter $S P, S K$, and NK} binding by $S P, S K$, and $N K$

The first type of tachykinin binding site is detectable in both brain and peripheral tissues (Table 3 ) and is here referred to as the SP binding site since SP is about 3 orders of magnitude more potent than either SK or NK in displacing BHSP from this binding site. The SP binding site has a $K_{d}$ of approximately 1.0 nM (Mantyh et al., 1984c) and the SP receptor expressed by cells in the gastrointestinal (GI) tract (Burcher et al., 1986) appears to have a similar pharmacology to that of the SP receptor in brain (Torrens et al., 1983).

The second binding site is found only in the CNS (Table 3) and is here referred to as the NK binding site. Both NK and

\begin{tabular}{|c|c|c|c|c|}
\hline Investigator(s) & & SP & SK & NK \\
\hline Henry et al., 1987 & & NK-1 & NK-2 & NK-3 \\
\hline Henry et al., 1987 & & TK-1 & TK-2 & TK-3 \\
\hline Henry et al., 1987 & & SP-P & NK-A & NK-B \\
\hline Laufer et al., 1985 & & SP-P & SP-E & SP-N \\
\hline Regoli et al., 1985 & & NK-P & NK-A & NK-B \\
\hline Piercey et al., 1985 & & $\mathrm{SP}_{2}$ & $\mathrm{SP}_{1}$ & $\mathrm{SP}_{1}$ \\
\hline Buck et al., 1984a & & SP-P & SP-K & SP-E \\
\hline Lee et al., 1982 & SP-P & SP-P & SP-E & SP-E \\
\hline Melchiorri and Negri, 1984 & TK-2 & TK-1 & TK-3 & TK-3 \\
\hline Erspamer, 1981 & PHYS & $\mathbf{S P}$ & KAS & ELE \\
\hline Agonist & PHYS & SP & $\mathrm{K}$ & $\mathrm{E}$ \\
\hline
\end{tabular}



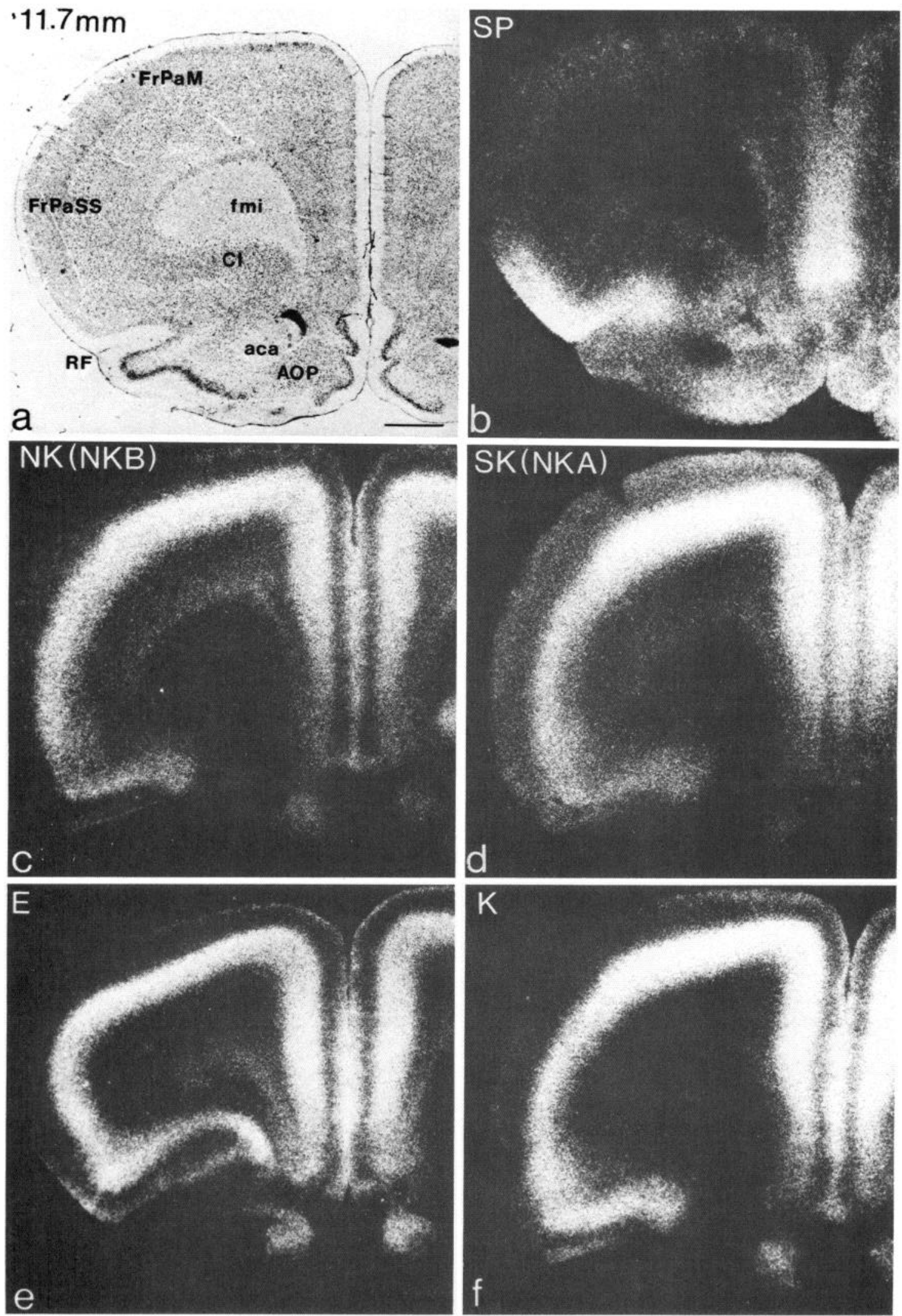

Figure 1. Autoradiographic localization of tachykinin receptor binding sites in coronal sections of the rat brain. In Figures 1-6, $a$ is a light-field photomicrograph of the rat brain section that was stained with cresyl violet to aid in the orientation of the tissue section, whereas $b-f$ are darkfield autoradiograms of adjacent sections that demonstrated the distribution of binding sites for the following Bolton-Hunter labeled tachykinins: $b$, substance $\mathrm{P}(\mathrm{SP}) ; c$, neuromedin $\mathrm{K}(\mathrm{NK}) ; d$, substance $\mathrm{K}(\mathrm{SK}) ; e$, eledoisin $(\mathrm{E})$; and $f$, kassinin $(\mathrm{K})$. For orientation purposes, we have given the distance each coronal section lies in front of the interaural line in upper left-hand corner of $a$. All abbreviations are from the atlas of Paxinos and Watson (1982). In the photomicrographs $b-f$, the light areas correspond to concentrations of binding sites. Unless otherwise noted, all white areas 
SK are more potent than SP in displacing either NK or SK from these sites, but NK appears to be more potent than SK in displacing either BHNK or BHSK from rat brain sections. Thus, in laminae 4 and 5 of the rat cerebral cortex the $K_{I}$ 's for displacing BHNK are $0.1 \mathrm{~nm}$ for NK, $1.0 \mathrm{nM}$ for SK, and $95 \mathrm{~nm}$ for SP (see Fig. 11A), whereas in this same tissue the $K_{I}$ 's for displacing BHSK are $0.1 \mathrm{~nm}$ for NK, $1.0 \mathrm{~nm}$ for SK, and $40 \mathrm{~nm}$ for SP (Fig. 11B).

The third type of receptor that is found only in peripheral tissues (Table 3 ) is here referred to as the SK binding site since both SP and NK appeared to be less potent than SK in displacing BHSK from its peripheral binding site and since no BHNK binding sites have been found in any peripheral tissue we examined. This binding site in the external circular muscle of the rat colon has a $K_{d}$ of $2.0 \mathrm{~nm}$ and $K_{i}$ 's of $3000 \mathrm{~nm}$ for SP, $2.5 \mathrm{~nm}$ for SK, and $90 \mathrm{~nm}$ for NK (Fig. 11C). This site appears to be expressed only in the GI tract and has not been reported to be present in the brain.

To date, no single system of tachykinin receptor nomenclature has yet become conventional. We refer here to the observed binding sites as SP, SK, and NK without prejudice toward the various nomenclatures (Table 4) currently in use (see below).

Comparison of specific binding sites for ${ }^{125} I$-Bolton-Hunter SP, $S K, N K, E$, and $K$ in the CNS

In general, the distribution of SP, NK, SK, K, and E binding sites in the brain is in close agreement with previous findings (Shults et al., 1982, 1984; Quirion et al., 1983; Quirion and Pilapil, 1984; Mantyh et al., 1984a-e, 1987; Rothman et al., 1984a, b; Beaujouan et al., 1986; Buck et al., 1986). In describin£ the distribution of binding sites we will therefore concentrate on areas where a clear difference between SP and NK binding could be seen. Probably the most prominent difference between SP and NK binding sites is in the cerebral cortex. As shown on Figures 1-5, there is a heavy concentration of NK binding sites in laminae 4 and 5 of the cerebral cortex, whereas SP binding sites are detcctablc and only in low concentrations in laminae 1 and 2 of the cerebral cortex. The one area of cortex that expressed a high concentration of SP binding sites was the striate and entorhinal cortex, a region of the cortex involved in gustatory and visceral integration.

Other areas showing a marked difference between SP and NK binding sites are the ventral tegmental area and superficial superior colliculus (Figs. 4, 5). Whereas there are only very low concentrations of SP binding sites in the VTA, there are moderatc concentrations of NK binding sites in this region (Fig. 4). In the superficial layer of the superior colliculus, this situation is reversed. Here, one finds a very heavy concentration of SP binding sites but only a low concentration of NK binding sites.

There is a comparable situation in the dorsal raphe and median raphe. In the dorsal raphe there is a very heavy concentration of SP binding sites but only a low concentration of NK binding sites. This is reversed in the median pontine raphe; there is a moderate concentration of NK binding sites but few if any SP binding sites in this nucleus.

In the brain stem there are several areas where there is a marked difference in the expression of SP and NK binding sites
(Fig. 6). SP binding sites are found in high concentrations over several motor nuclei (including 7, 10,12, and ambiguous), whereas NK binding sites are undetectable in these motor nuclei. This is in contrast to sensory nuclei such as the nucleus of the solitary tract, where there are very high concentrations of both NK and SP binding sites. This distinction of NK binding sites being associated with sensory regions, whereas SP binding sites are associated with both motor and sensory regions also holds true for the spinal cord. Whereas SP binding sites are expressed by areas of the spinal cord involved in both sensory (laminae 1 and 2) and motor (laminae 6-9, Onuf's nucleus) function, NK binding sites are expressed only in laminae 1 and 2, which are known to be involved in sensory functions. In the retina specific binding sites for SP, SK, NK, E, and $\mathrm{K}$ are present over the inner plexiform layer (Fig. 7).

Comparison of specific binding sites for ${ }^{125} I-B o l t o n-H u n t e r ~ S P$, $S K, N K, E$, and $K$ in peripheral tissues

Unlike the brain, where BHNK, BHSK, BHE, and BHK labeled similar brain areas in peripheral tissues no BHNK sites could be detected, whereas BHSK, BHE, and BHK labeled similar structures. For this reason and because of the displacement studies (Fig. 11C), we refer to these peripheral binding sites as SK sites.

In the esophagus, SP binding sites are present in low to moderate concentrations over the muscularis externa and in low concentrations over the muscularis mucosae, whereas SK binding sites are found in high concentrations only in the muscularis mucosae (Fig. 8). In the colon (Fig. 9), SP and SK binding sites were expressed in high concentrations by the external circular muscle and in low concentrations by neurons in the myenteric plexus and longitudinal muscle. In the bladder (Fig. 10), both SP and SK binding sites were expressed in very high concentrations by the external muscle.

\section{Variability of specific binding sites for ${ }^{125} I$-Bolton-Hunter $S P$, $S K, N K, E$, and $K$ in the CNS and peripheral tissues}

The distribution and concentration of tachykinin binding sites did not vary significantly from animal to animal or day to day with 2 notable exceptions. The first was binding in the striatum. In previous experiments we and others showed that a high concentration of SP binding sites was present in the striatum and that this appeared to be localized to neurons as kianic acid injection into the striatum greatly reduced the number of SP binding sites (Mantyh and Hunt, 1986). In rat R4, however, we did not observe a high concentration of binding sites in the striatum using either BHSP or ${ }^{3} \mathrm{H}-\mathrm{SP}$ (New England Nuclear) run on different days. In 10 other rats, BHSP binding in the striatum was normal.

The second variable binding was in rat R7 (Fig. 3), which had normal SP binding (including striatum) but did demonstrate differences in BHNK, BHSK, BHE, and BHK binding in the hippocampus and medial habenula. We repeated the binding experiments on rat $\mathrm{R} 7$ using all the ligands on subsequent days with the same results. In 9 other rats, the patterns of BHNK, BHSK, BHE, and BHK were very similar in these areas and appeared similar to Figure $3 c$.

correspond to specific binding sites in that labeling was absent in adjacent sections when an excess (10 $\left.{ }^{-6} \mathrm{M}\right)$ of cold ligand was added to the incubation medium. Here (Fig. 1), notice that the highest concentration of binding sites for SP is over the outer laminae of the insular cortex, whercas for NK, SK, E, and K the binding sites are densest over laminae 4 and 5 . Scale bar, $1 \mathrm{~mm}$. 

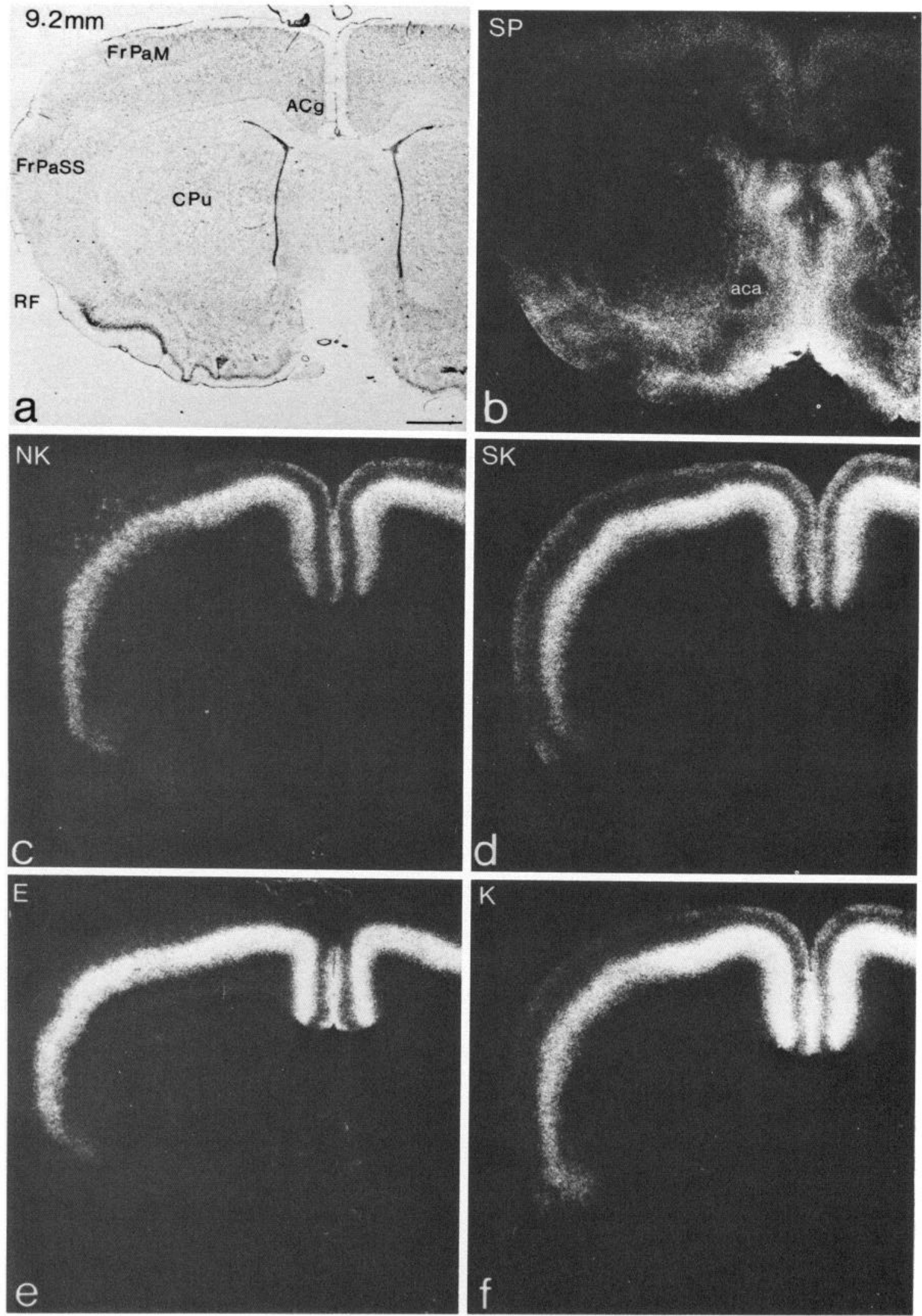

Figure 2. Autoradiographic localization of tachykinin binding sites in the cerebral cortex and striatum. Note the high concentration of NK, SK, $\mathrm{E}$, and $\mathrm{K}$ binding sites in laminae 4 and 5 of the cerebral cortex, whereas SP binding sites are expressed in high concentrations by the nucleus accumbens. See Figure 1 for explanation. Scale bar, $1 \mathrm{~mm}$. 

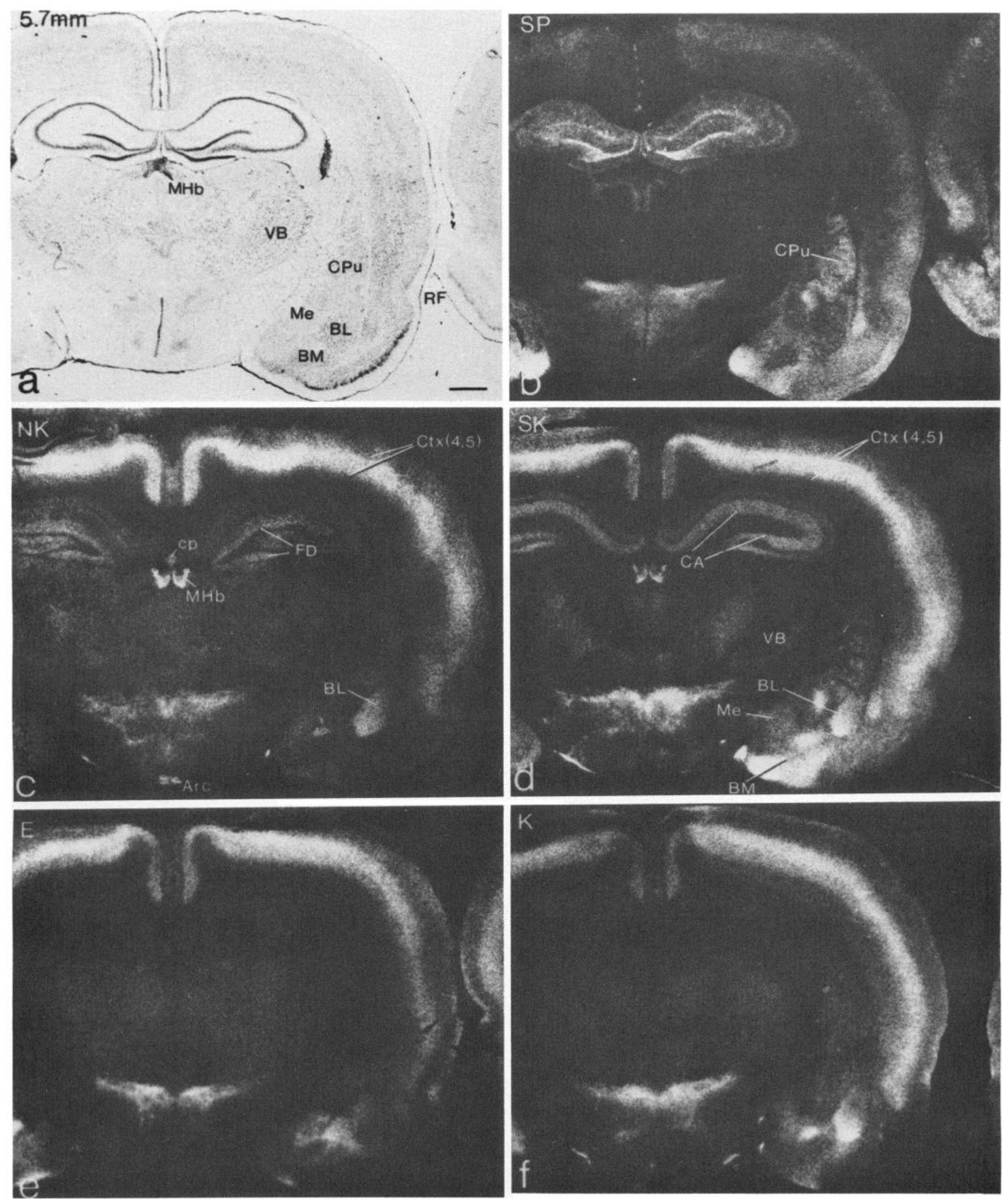

Figure 3. Autoradiographic localization of tachykinin binding sites in the cerebral cortex, hippocampus, hypothalamus, and amygdala in rat R7. The major differences to note are that, whereas NK, SK, E, and $\mathrm{K}$ are present in high concentrations in laminae 4 and 5 of the cerebral cortex, SP binding concentrations are present in low concentration in laminae 1 and 2 . Note also that in $c-f$ there are minor differences in the location and concentration of binding sites among these 4 ligands. For example, whereas BHNK and BHSK binding sites are expressed by the medial habenula, $\mathrm{BHE}$ and BHK sites are not seen in $e$ and $f$. This was the only rat of the 10 we examined in which we observed these differences. In all other animals, SK, NK, E, and K binding sites were nearly identical and were similar to $c$ or $d$. See Figure 1 for explanation. Scale bar, $1 \mathrm{~mm}$. 

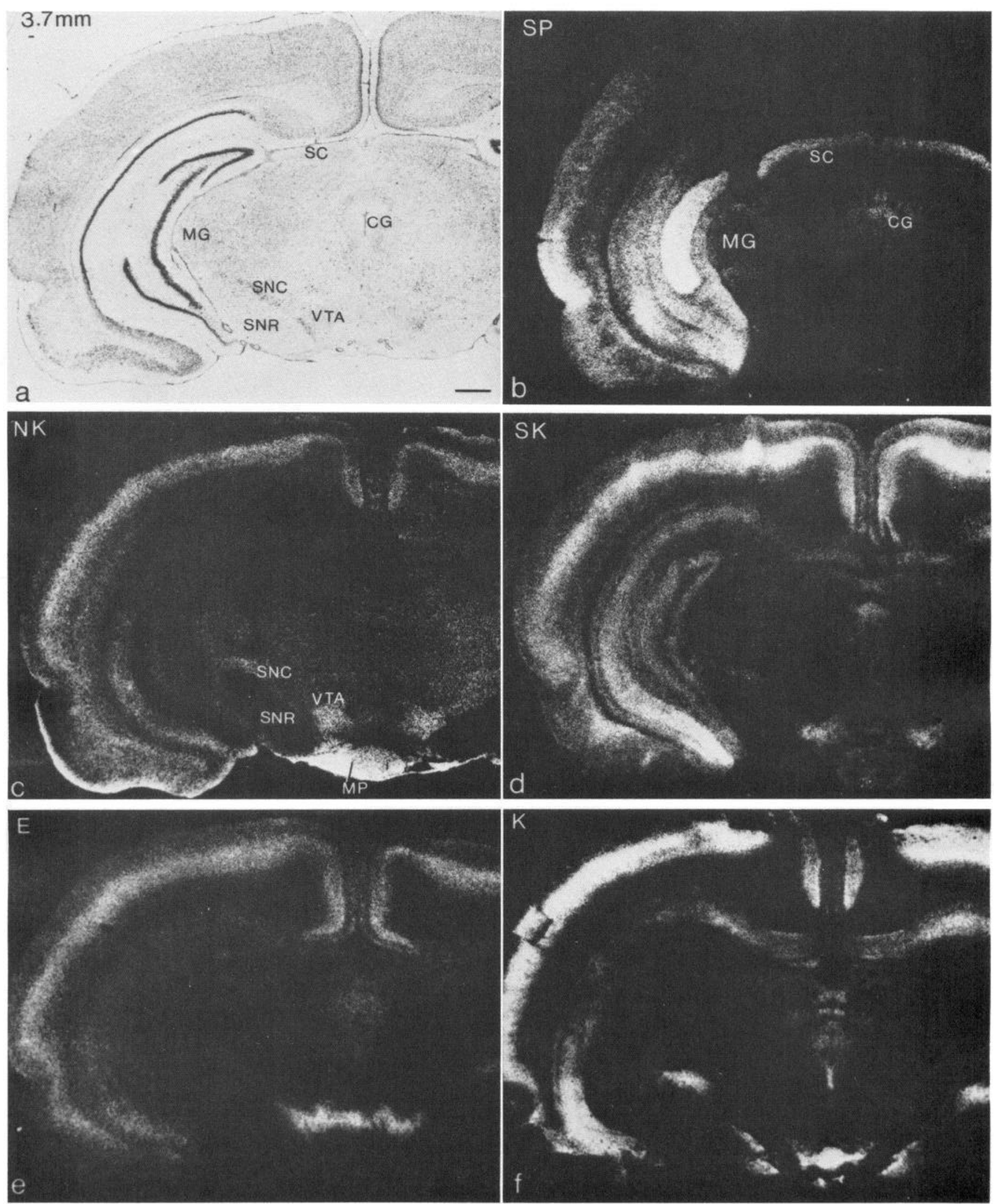

Figure 4. Autoradiographic localization of tachykinin binding sites in the cerebral cortex, hippocampus, and midbrain. Note the moderate concentration of NK, SK, E, and K binding sites in the ventral tegmental areas, whereas only a low concentration of SP binding sites is present in this area. See Figure 1 for explanation. Scale bar, $1 \mathrm{~mm}$. 

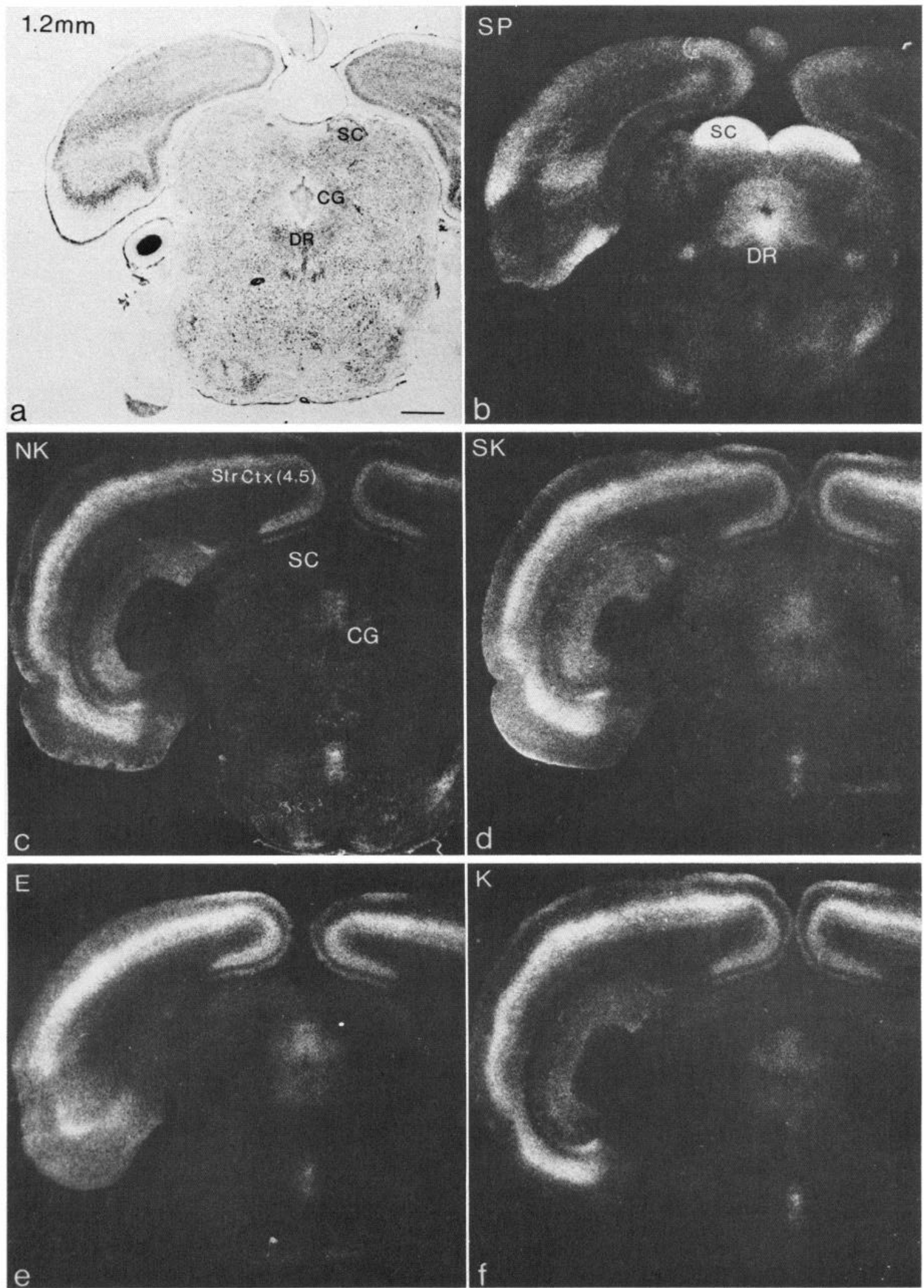

Figure 5. Autoradiographic localization of tachykinin binding sites in the striate cortex and midbrain. Note the differences in the distribution of SP versus NK, SK, E, and K binding sites in the striate cortex. Also note that, whereas SP binding sites are expressed in high concentrations in the superficial layers of the superior colliculus and dorsal raphe, NK, SK, E, and K binding sites are expressed in low concentrations in these areas. See Figure 1 for explanation. Scale bar, $1 \mathrm{~mm}$. 


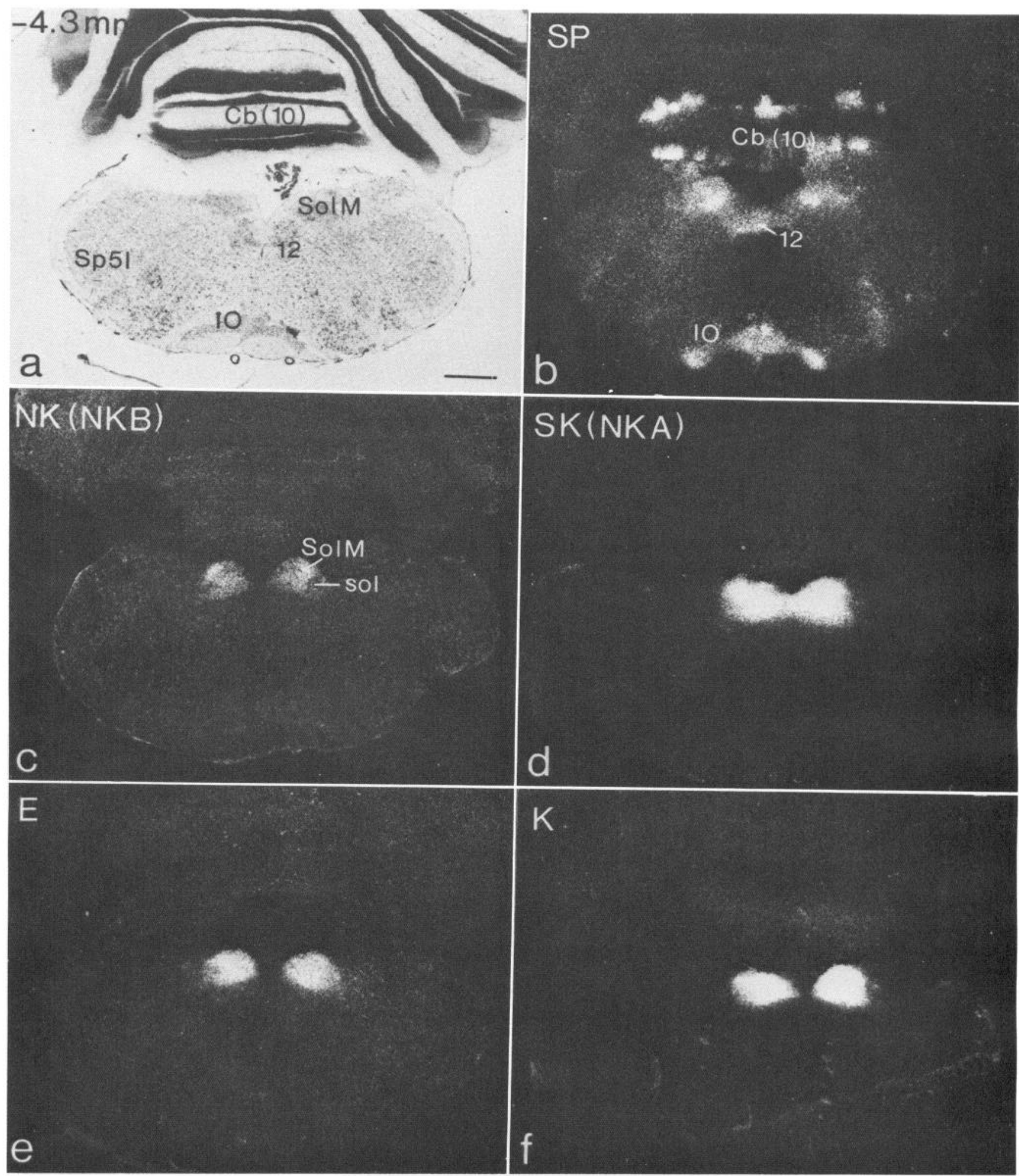

Figure 6. Autoradiographic localization of tachykinin binding sites in the medulla and cerebellum. Note that, whereas SP binding sites are expressed by lobule 10 in the cerebellum, the hypoglossal nucleus (12th cranial nucleus), and the inferior olive, NK, SK, E, and K binding sites are expressed in high concentrations in the nucleus of the solitary tract. See Figure 1 for explanation. Scale bar, $1 \mathrm{~mm}$. 


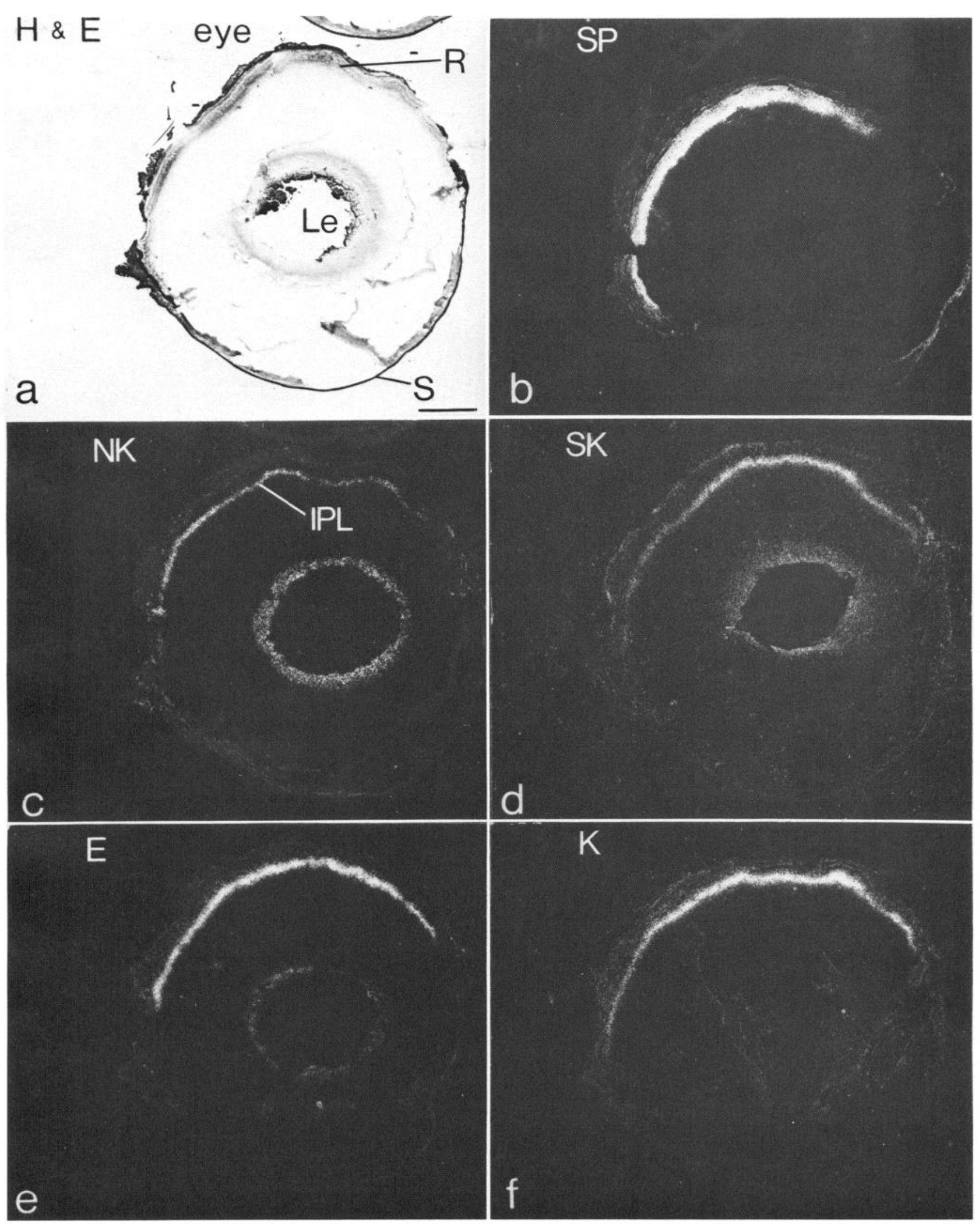

section, whereas $b-f$ are dark-field autoradiograms of adjacent sections that demonstrate the distribution of binding sites for Bolton-Hunter labeled: $b$, substance $\mathrm{P}(\mathrm{SP}) ; c$, neuromedin $\mathrm{K}(\mathrm{NK}) ; d$, substance $\mathrm{K}(\mathrm{SK}) ; e$, eledoisin (E); and $f$, kassinin $(\mathrm{K})$. In the photomicrographs $b-f$, the light areas correspond to high concentrations of binding sites. Unless otherwise noted, all white areas correspond to specific binding sites in that the binding sites were absent in adjacent sections where an excess $\left(10^{-6} \mathrm{M}\right)$ of the appropriate cold peptide was added to the incubation medium. Note that, whereas specific SP, NK, SK, E, and K binding sites are localized to the inner plexiform layer, the binding sites associated with the lens are not displaced in the presence of $10^{-6} \mathrm{M}$ cold peptide and are therefore nonspecific binding sites. Scale bar, $1.0 \mathrm{~mm}$. 


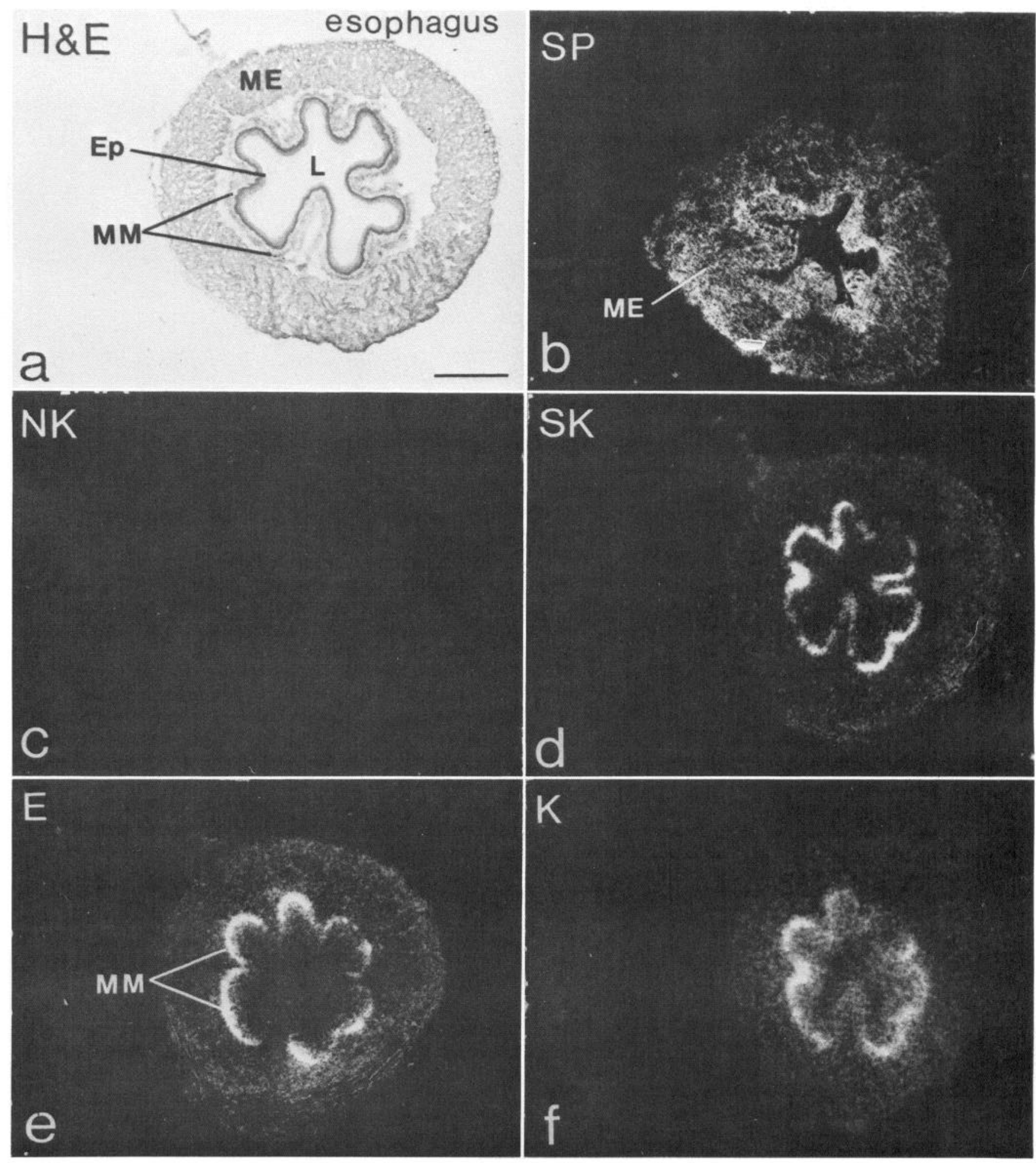

Figure 8. Autoradiographic localization of tachykinin receptor binding sites in a transverse section of the esophagus. Note that, whereas SP binding sites are expressed by the external muscle layer of the esophagus, SK, E, and $\mathrm{K}$ binding sites are expressed in moderate concentrations by the muscularis mucosae. Also note that no specific NK binding sites could be detected. Scale bar, $1.0 \mathrm{~mm}$.

\section{Discussion}

\section{Tachykinin receptor classification}

Receptor classification for classical transmitters has been based largely on the use of specific high-affinity antagonists; but for the tachykinins, no such antagonists have yet been discovered or produced. Thus, tachykinin receptors have been classified in the past mainly on the use of agonists in pharmacological experiments (Lee et al., 1982, 1986); recently, radioligands have also been employed (Torrens et al., 1983, 1984, 1985; Viger et al., 1983; Beaujouan et al., 1984, 1986; Cascieri and Liang, 1984; Ninkovic et al., 1984; Cascieri et al., 1985; Maggio et al., 

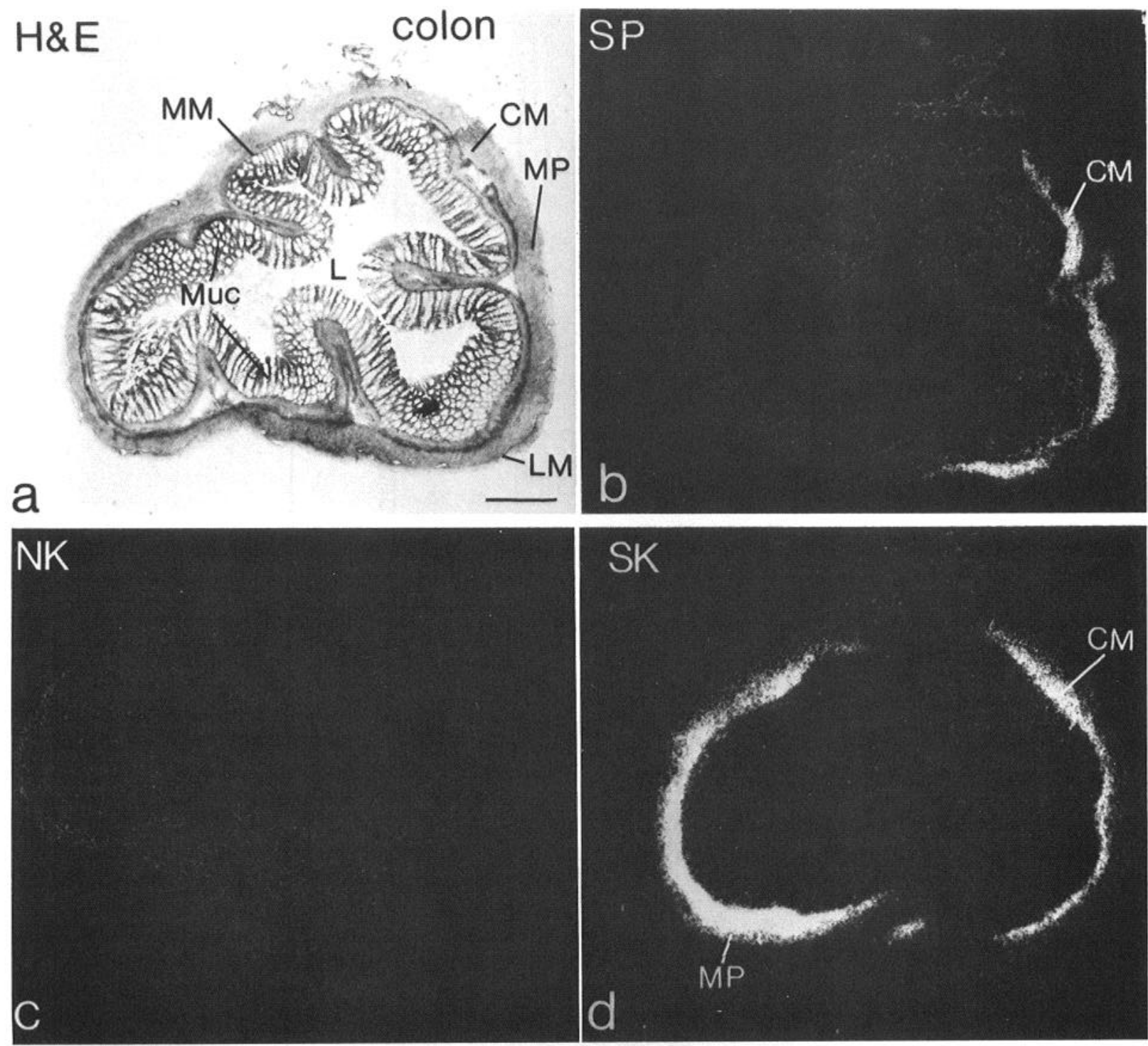

SK

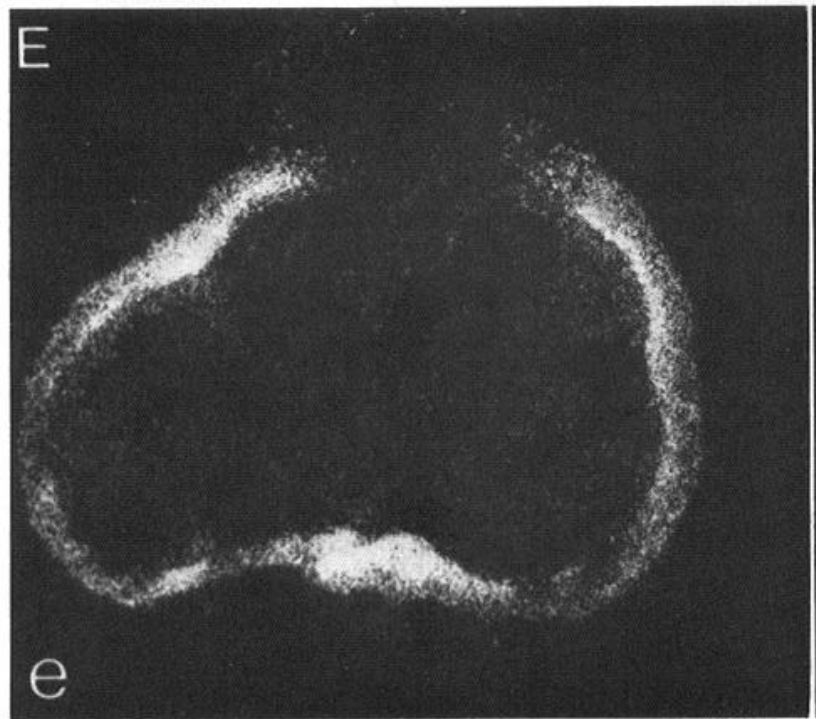

K
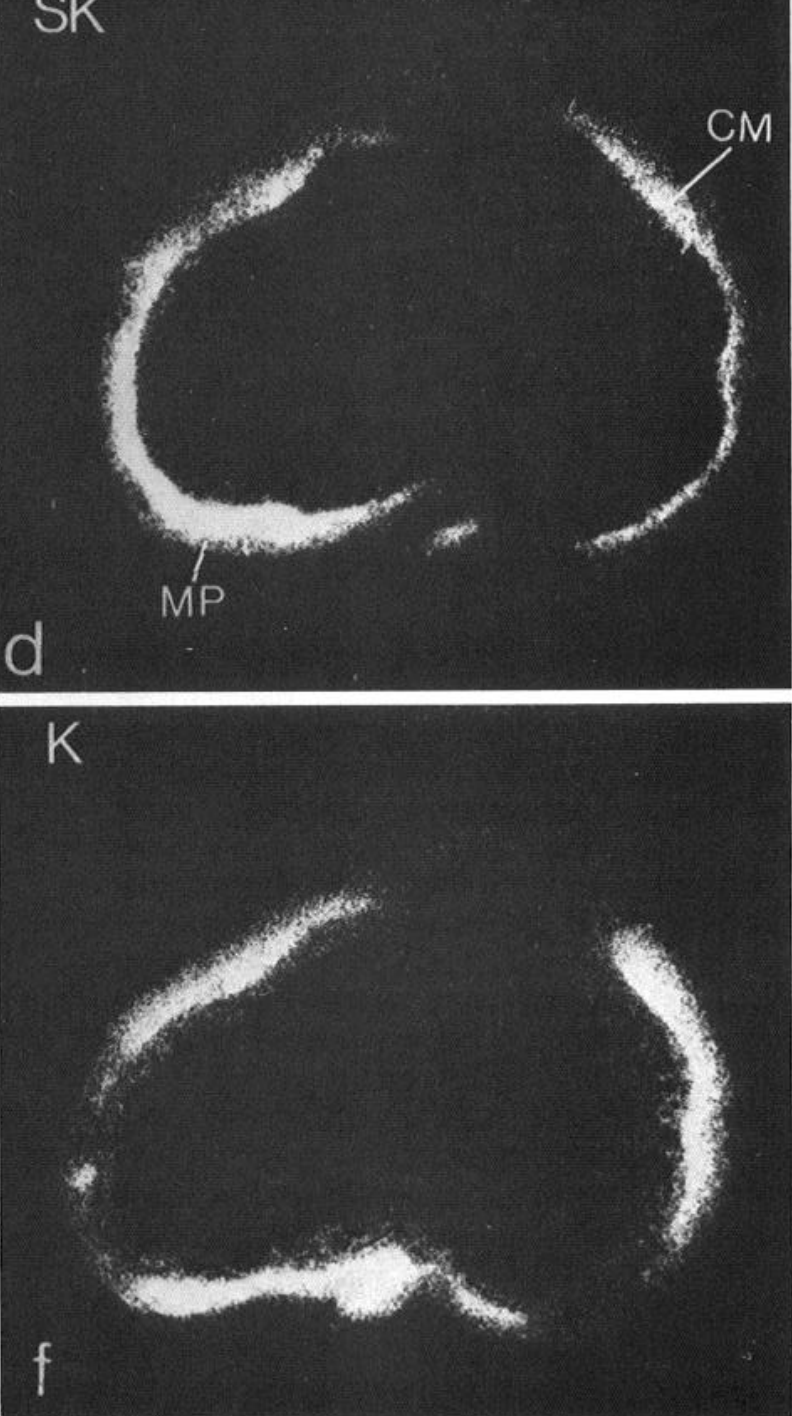

d

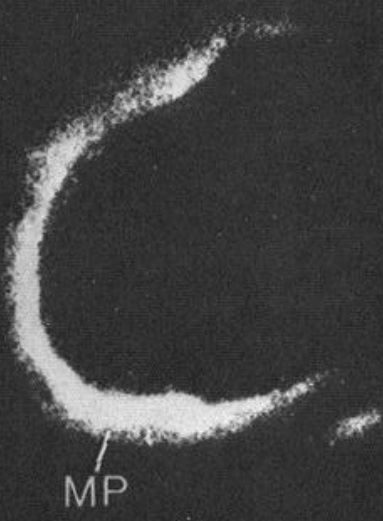

K

Figure 9. Autoradiographic localization of tachykinin receptor binding sites in transverse sections of the rat colon. Note that, while SP, SK, E, and $\mathrm{K}$ binding sites are expressed in moderate concentrations by the external circular muscle, no specific NK binding sites could be detected. Scale bar, $1.0 \mathrm{~mm}$. 


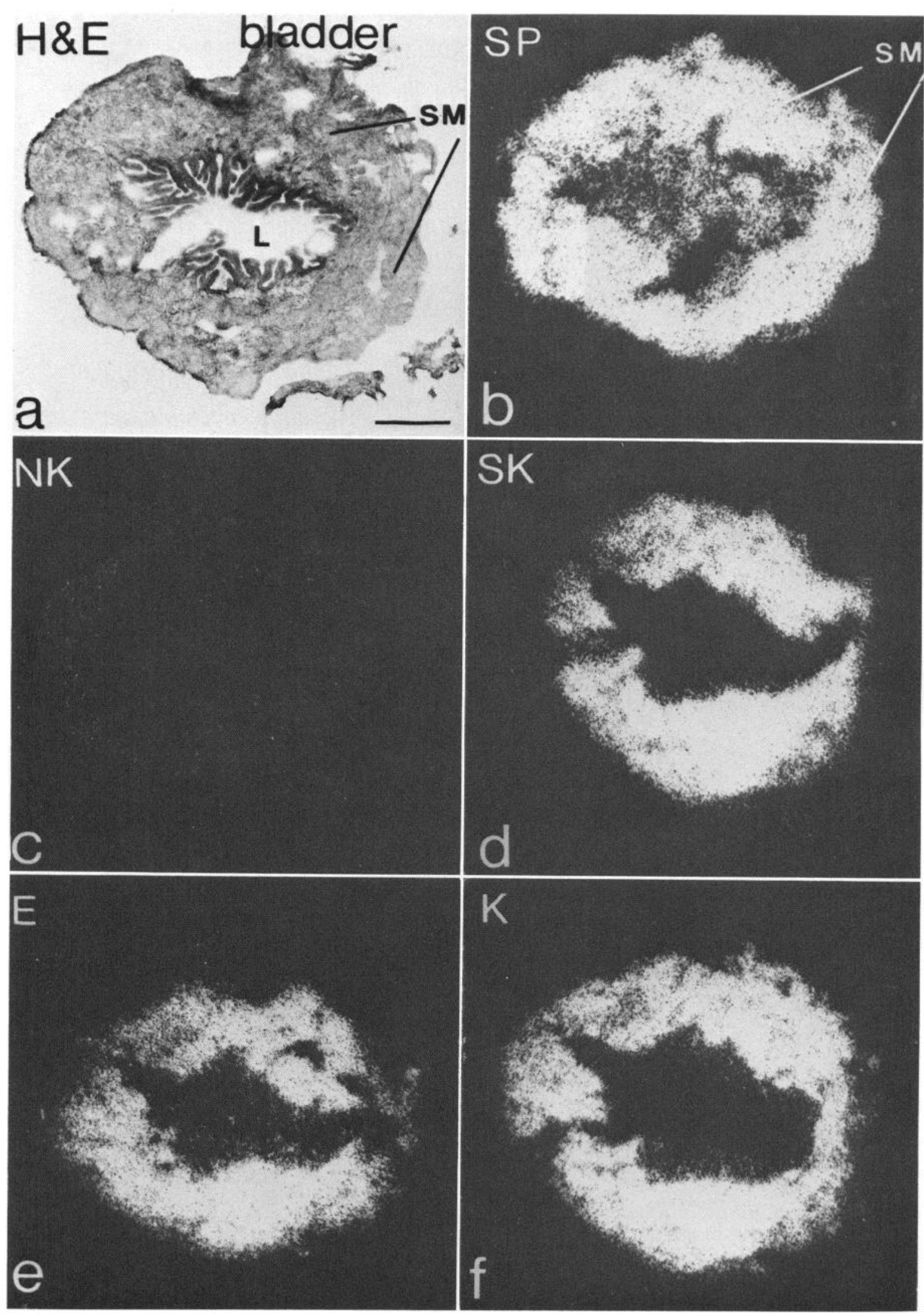

Figure 10. Autoradiographic localization of tachykinin receptor binding sites in transverse sections of the rat bladder. Note that, whereas SP, SK, $\mathrm{E}$, and $\mathrm{K}$ binding sites are expressed by the external muscle, no NK binding sites could be detected. Scale bar, $1.0 \mathrm{~mm}$. 
A.

'23/-BHNK DISPLACEMENT IN RAT CEREBRAL CORTEX
B.

${ }^{28}$ I-BHSK DISPLACEMENT IN RAT CEREBRAL CORTEX
C.

${ }^{125} \mathrm{I}-\mathrm{BHSK}$ DISPLACEMENT IN RAT COLON
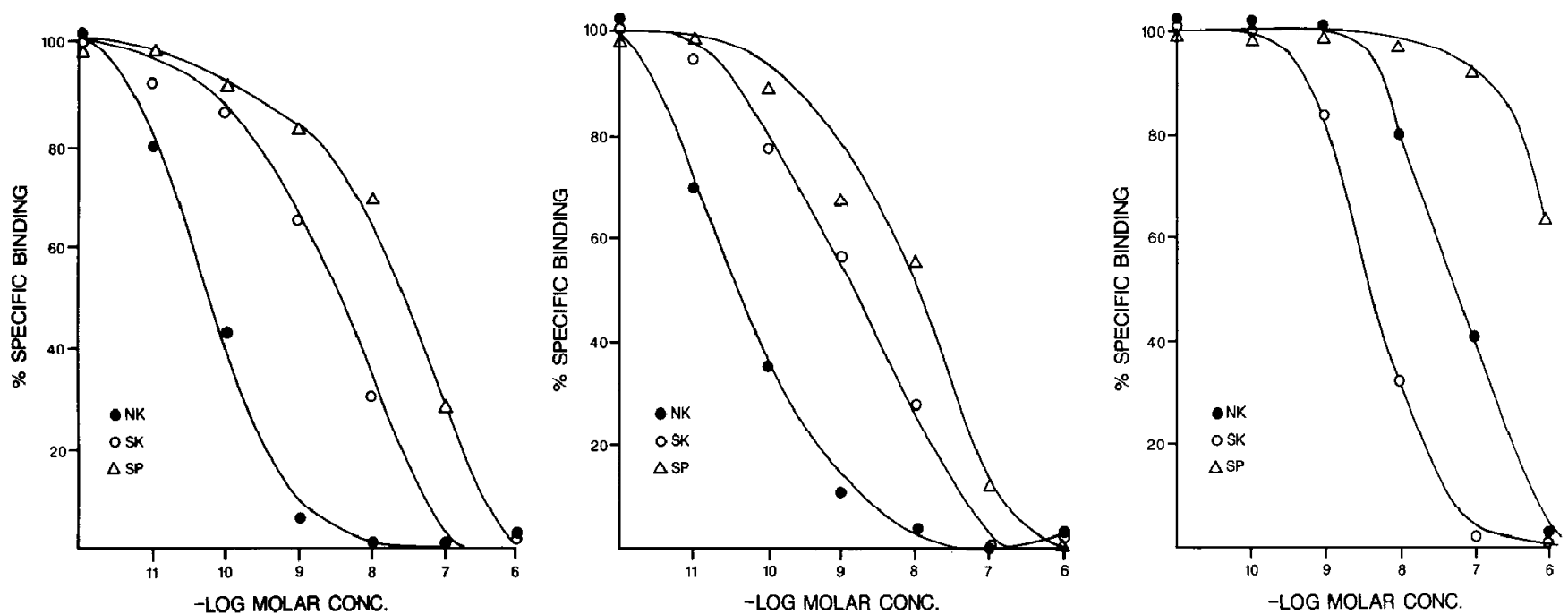

Figure 11. A, Inhibition curves for ${ }^{125}$ I-BHNK binding to laminac 4 and 5 of the somatosensory arca of the cercbral cortex. Slides were incubated with ${ }^{125}$ I-BHNK with graduated concentrations of unlabeled NK, SK, or SP. The optical densities were determined for the high-density binding sites and plotted against the concentration of cold peptide present. $B$, Inhibition curves for ${ }^{125}$ I-BHSK binding in laminae 4 and 5 of the somatosensory area of the cerebral cortex. $C$, Inhibition curves for ${ }^{125} \mathrm{I}-\mathrm{BHSK}$ binding in the circular muscle of the rat colon. 'The data are from a representative experiment. Each point represents the mean of a triplicate determination where the SE is less than $15 \%$ of the mean.

1985; Bergstrom et al., 1987). Each method is based on assumptions that are difficult to verify experimentally (Maggio, 1988); as a result, tachykinin receptor nomenclature has been a matter of active discussion and dispute in recent years (Henry et al., 1987). Some of the nomenclature systems currently in use are given in Table 4; since different nomenclature systems are defined by different criteria in different systems, the equivalences implied in Table 4 are only approximate.

In the past, when SP was believed to be the only mammalian tachykinin, the most popular tachykinin receptor classification (Lee et al., 1982) divided mammalian peripheral tissues into 2 categories based on agonist potency. In one group of tissues, the tachykinins tested were roughly equipotent; in the other group of tissues, tachykinins bearing a branched aliphatic residue (Val, Ile) at position $X$ in the defining sequence -Phe-X-Gly-LeuMet- $\mathrm{NH}_{2}$ were much more potent than the tachykinins with an aromatic (Phe, Tyr) residue at this position (Fig. 1). The tissues were said to contain SP receptors of the SP-P and SP-E types, respectively. While it is now clear that the mammalian tachykinin system of peptides and receptors is more complex than supposed at the time, the division of mammalian tachykinins and tachykinin receptors into 2 broad categories based on the nature (aliphatic or aromatic) of the amino acid at position $\mathrm{X}$ remains valid. The present study mapping the tachykinin binding sites of rat tissues using 14 tachykinin radioligands showing specific binding is consistent with these previous findings.

Most of the binding and autoradiographic studies on tachykinin receptors have employed peptides labeled with ${ }^{125} \mathrm{I}$ in the form of a Bolton-Hunter group, that is, a 3-[3-iodo-4-hydroxyphenyl]propionyl group on what was a free amino group in the native peptide. For a peptide the size of a tachykinin, that modification makes a considerable difference in the charge, size, and hydrophobicity, and the radioligand may not have the same receptor specificity as the native peptide. Indeed, it has been shown (Lee et al., 1986; Bergstrom et al., 1987) that addition of a Bolton-Hunter group can affect the receptor specificity of certain aliphatic tachykinins. Therefore, we have also employed radioligands other than the Bolton-Hunter conjugates in the present study. While NK is at present the leading candidate for physiological ligand at most aliphatic tachykinin binding sites in the CNS and SK the leading candidate at most aliphatic tachykinin binding sites in peripheral tissues, there remain many uncertainties. For example, both binding and pharmacological experiments have made it clear that tachykinin receptors are not fastidiously specific, and cross-talk between ligands and receptors in this neuropeptide family may occur in vivo as well as in vitro.

\section{$S P$-preferring receptor}

In the present report we have shown that there are at least 3 types of tachykinin binding sites in the rat. The first type of binding site, referred to as the SP site, is found in both the brain and periphery. Displacement experiments demonstrate that SP is approximately 1000 times as potent as either SK or NK at displacing BHSP in both the brain (rat cerebral cortex) and the periphery (canine chief cells, unpublished observations), and thus this binding site appears to be relatively specific for SP. These results are in general agreement with what is known about the distribution of SP. Authentic SP appears to be present in both the brain and peripheral tissues (Chang and Leeman, 1970; Nilsson et al., 1975; Franco et al., 1979; Maggio et al., 1983; Kanazawa et al., 1984; Maggio, 1985; Deacon et al., 1987) and should be available to occupy the SP binding site. The question of whether there are subtypes of SP receptors in the brain and periphery remains open. In the present experiments we have not addressed this question, for while possible evidence for the existence of subtypes of SP receptors has been presented, none of the techniques used to address the question are definitive since possible artifacts due to differences in degrading enzymes and receptor accessibility cannot, at present, be ruled out. 


\section{NK-preferring receptor}

The second type of binding site which we have called the NK site is found only in the CNS. Displacement experiments (Fig. $11 \mathrm{~A}$ ) suggest that $\mathrm{NK}$ is approximately 10 times as potent as SK and 1000 times as potent as SP in displacing BHNK from binding sites in the brain (cerebral cortex), and NK is also more potent than either SK or SP in displacing BHSK (Fig. 11B) from its binding site. We could not detect this type of receptor in any peripheral tissue we examined; i.e., we could not find any specific binding sites for any NK ligand in any rat peripheral tissues we examined, or in any segment of the canine (Mantyh et al., 1988b) or human GI tract (Mantyh et al., 1988a). This NK binding site also appears to be labeled by kassinin and eledoisin radioligands since these amphibian (K) and molluscan (E) tachykinin analogs labeled a similar set of regions throughout the rat brain. While NK is somewhat more potent than SK in displacing either BHNK or BHSK, both NK and SK are present in the brain (Kangawa et al., 1983; Kimura et al., 1983; Maggio et al., 1983; Kanazawa et al., 1984; Minamino et al., 1984). Since we do not know the actual concentration of peptide at the receptor binding sites we feel it is premature to rule out SK as a possible endogenous ligand for this site.

\section{SK-preferring receptor}

The third type of receptor binding site is found only in peripheral tissues. We have referred to it as the SK binding site since SK appears to be the endogenous ligand and is the most potent tachykinin analog in displacing BHSK. Thus, in the colon SK is approximately 35 times as potent as NK and 1000 times as potent as SP in displacing BHSK from the circular muscle of the colon. One additional reason for referring to this receptor as SK is that it has been reported (Deacon et al., 1987) that immunoreactive NK is not detectable in guinea pig GI tissue. However, mRNA for NK has been detected in similar tissues in cow (Kotani et al., 1986). The explanation for this apparent paradox is unknown. However, in light of the displacement experiments, the presence of BHNK binding sites in brain but not in peripheral tissues, and the presence of detectable NK in the brain but not in peripheral tissues, we have tentatively named this peripheral tachykinin receptor SK. The specificity of this peripheral bovine SK receptor has recently been examined in a frog oocyte expression system (Masu et al., 1987) and the amino acid and nucleotide sequence of this receptor described (Harada et al., 1987). These data are in agreement with the present data in that the SK receptor is expressed in peripheral tissues and shows a preference for SK.

\section{Physiological functions of tachykinin receptors}

While it appears from the present result that there are at least 3 different types of tachykinin receptors in the rat, determining which physiological functions these receptor binding sites may mediate, especially in the brain, is less clear. The major reason for the difficulty in assigning any specific neuronal function is the complexity of the brain, but of considerable importance is the degree of resolution obtainable with the autoradiographic technique. For example, while spinal motor neurons are sufficiently large and well delineated that specific binding sites have been shown to be associated specifically with these neurons (Helke et al., 1984; Charlton and Helke, 1985) in other areas such as the striatum, where neurons, glia, and fibers of passage are intermixed, it is difficult to determine exactly which cell type expresses the binding site. This difficulty is underlined by the observation that glia have been shown to express high concentrations of SP binding sites both in culture (Torrens et al., 1986; Shults et al., 1987) and in situ after neuronal injury (Zimmerman et al., 1988). Thus, in most areas of the brain (i.e., cerebral cortex, amygdala, striatum) while one assumes that the tachykinin receptors are expressed predominately by neurons, it is possible that glia also express tachykinin receptors in these brain areas. In some areas of the brain stem and spinal cord, a defined role for SP and NK receptors is beginning to emerge. Whereas SP receptors are concentrated in both motor and sensory areas, the NK binding sites appear to be associated almost exclusively with the sensory system. Thus, SP binding sites are present over brain-stem motor nuclei $3,7,10,12$, and around ventral spinal motor neurons, preganglionic sympathetic neurons and Onuf's nucleus (Hclke ct al., 1984). No detcctablc concentration of NK binding sites is associated with these areas. In contrast, in sensory areas of brain stem and spinal cord (such as laminae 1 and 2 of the spinal trigeminal nucleus pars caudalis and laminae 1 and 2 of the spinal cord), both SP and NK receptors are present in high concentrations. Since incoming peptide containing C-fibers terminate heavily in these laminae, it is assumed that these binding sites are involved in processing incoming sensory information.

While it is difficult to define a function for tachykinin binding sites in the CNS, both the present study and previous pharmacological studies suggest that tachykinins play an important regulatory role in a wide variety of peripheral tissues (Pernow, 1983). One of the best-established functions for SP in the peripheral tissues is its potent spasmogenic effects on several peripheral smooth muscles. In the present study, we have demonstrated that SP and SK binding sites are present over smooth muscle in the esophagus, colon, and bladder. In the esophagus the smooth muscle of the muscularis mucosae expressed only SK binding sites and the muscularis externa SP binding sites, whereas in the colon and bladder both SP and SK binding sites are present over similar muscle layers. In the rat GI tract, SP and SK have repeatedly been shown to cause a potent contraction of the smooth muscle and are probably involved in gastric motility (Pernow, 1983). In the bladder, SP has been shown to be involved in the micturition response, which is apparently initiated by SP and SK released from visceral sensory nerves in which SP and SK are coexpressed (Maggio and Hunter, 1984) and presumably co-released. In addition, it has recently been demonstrated that binding sites for SP and SK can be differentially regulated since SP-preferring receptors, but not SK or $\mathrm{NK}$, are ectopically expressed in high concentrations by arterioles, venules, and lymph nodules in human inflammatory disease affecting peripheral tissues (Mantyh et al., 1988a). These results support previous pharmacological experiments suggesting that tachykinins regulate a wide variety of peripheral actions, including gut motility and micturition, and there are at least 2 different tachykinin receptors in peripheral tissues whose expression appears to be independently regulated.

In summary, we have shown that there are at least 3 distinct tachykinin receptors detectable in rat brain and peripheral tissues. We have referred to these receptors as SP, NK, and SK according to the different ligands that preferentially bind to these binding sites, the inhibition constants displayed by the displacing peptides, and whether endogenous ligand is present to occupy the relevant binding site. Thus, SP receptors are found in both central and peripheral tissues, NK receptors in the CNS 
only, and SK receptors in peripheral tissues. We feel that this is the lowest order of complexity for subdivision of tachykinin receptors and that further distinctions may be expected with the possible discovery of new mammalian tachykinins, the cloning of the tachykinin receptors, and the development of specific tachykinin analogs.

\section{Appendix}

\begin{tabular}{|c|c|}
\hline \multicolumn{2}{|c|}{ Abbreviations used in the Figures } \\
\hline 12 & hypoglossal nucleus \\
\hline aca & anterior commissure \\
\hline $\mathrm{ACg}$ & anterior cingulate cortes \\
\hline Arc & arcuate nucleus of the hypothalamus \\
\hline AOP & anterior olfactory nucleus, posterior part \\
\hline $\mathrm{BH}$ & Bolton-Hunter \\
\hline $\mathrm{BL}$ & basolateral amygdaloid nucleus \\
\hline BM & basomedial amygdaloid nucleus \\
\hline $\mathrm{CA}$ & CA fields of Ammon's horn \\
\hline $\mathrm{Cb}(10)$ & cerebellum, lobule 10 \\
\hline CG & central gray \\
\hline $\mathrm{Cl}$ & claustrum \\
\hline $\mathrm{CM}$ & external circular muscle \\
\hline $\mathrm{cp}$ & choroid plexus \\
\hline $\mathrm{CPu}$ & caudate-putamen (striatum) \\
\hline $\operatorname{ctx}$ & cerebral cortex \\
\hline DR & dorsal raphe \\
\hline E & eledoisin \\
\hline Ep & epithelium \\
\hline FD & fascia dentata \\
\hline fmi & forceps minor of the corpus callosum \\
\hline FrPaM & frontal parietal cortex, motor area \\
\hline FrPaSS & frontal parietal cortex, somatosensory area \\
\hline $\mathrm{IO}$ & inferior olive \\
\hline IPL & inner plexiform layer \\
\hline $\mathrm{K}$ & kassinin \\
\hline $\mathrm{L}$ & lumen \\
\hline Le & lens \\
\hline LM & external longitudinal muscle \\
\hline $\mathrm{Me}$ & medial amygdaloid nucleus \\
\hline ME & muscularis externa \\
\hline MG & medial geniculate \\
\hline $\mathrm{MHb}$ & habenula, medial part \\
\hline MM & muscularis mucosa \\
\hline MP & medial mammillary nucleus, posterior part \\
\hline PHYS & physalaemin \\
\hline $\mathrm{R}$ & retina \\
\hline RF & rhinal fissure \\
\hline$S$ & sclera \\
\hline $\mathrm{SC}$ & superior colliculus \\
\hline SM & smooth muscle \\
\hline $\mathrm{SNC}$ & substantia nigra, pars compacta \\
\hline SNR & substantia nigra, pars reticulata \\
\hline sol & solitary tract \\
\hline SolM & nucleus of the solitary tract, medial part \\
\hline $\operatorname{Sp} 5 \mathrm{I}$ & nucleus of the spinal tract of 5 , pars interpolaris \\
\hline StrCtx & cerebral cortex, striate area \\
\hline TK & tachykinin \\
\hline VB & ventrobasal nucleus of the thalamus \\
\hline VTA & ventral tegmental area \\
\hline
\end{tabular}

\section{References}

Bartho, L., and P. Holzer (1985) Search for a physiological role of substance $\mathrm{P}$ in gastrointestinal motility. Neuroscience 16: 1-32.

Beaujouan, J. C., Y. Torrens, A. Viger, and J. Glowinski (1984) A new type of tachykinin receptor in the rat brain characterized by specific binding of an eledoisin derivative. Mol. Pharmacol. 26: 248254.

Beaujouan, J. C., Y. Torrens, M. Saffroy, and J. Glowinski (1986) Quantitative autoradiographic analysis of the distribution of binding sites for [ $\left.{ }^{125} \mathrm{I}\right]$ Bolton Hunter derivatives of eledoisin and substance $P$ in the rat brain. Neuroscience 18: 857-875.

Bergstrom, L., Y. Torrens, M. Saffroy, J. C. Beaujouan, S. Lavielle, G. Chassaing, J. L. Morgat, J. Glowinski, and A. Marquet (1987) $\left[{ }^{3} \mathrm{H}\right]$ Neurokinin B and ${ }^{125}$ I-Bolton Hunter eledoisin label identical tachykinin binding sites in the rat brain. J. Neurochem. 48: 125-133.

Bolton, A. E., and W. M. Hunter (1973) The labeling of proteins to high specific radioactivities by conjugation to a ${ }^{125}$ I-containing acylating agent. Biochem. J. 133: 529-538.

Bonner, T. I., A. C. Young, and H. U. Affolter (1987) Cloning and expression of rat and human substance $P$ genes. In Substance $P$ and Neurokinins, James L. Henry, ed., pp. 3-4, Springer-Verlag, New York.

Buck, S. H., and E. Burcher (1985) The rat submaxillary gland contains predominantly P-type tachykinin binding sites. Peptides 6: 10791084.

Buck, S. H., E. Burcher, C. W. Shults, W. Lovenberg, and T. L. O'Donohue (1984a) Novel pharmacology of substance K-binding sites: A third type of tachykinin receptor. Science 226: 987-989.

Buck, S. H., Y. Maurin, T. N. Burks, and H. I. Yamamura (1984b) High affinity ${ }^{3} \mathrm{H}$-substance $\mathrm{P}$ binding to longitudinal muscle membranes of the guinea pig small intestine. Life Sci. 34: 497-507.

Buck, S. H., C. J. Helke, E. Burcher, C. W. Shults, and T. L. O'Donohue (1986) Pharmacologic characterization and autoradiographic distribution of binding sites for iodinated tachykinins in the rat central nervous system. Peptides 7: 1109-1120.

Burcher, E., C. W. Shults, S. H. Buck, T. N. Chase, and T. L. O'Donohue (1984) Autoradiographic distribution of substance K binding sites in rat gastrointestinal tract: A comparison with substance P. Eur. J. Pharmacol. 102: 561-562.

Burcher, E., S. H. Buck, W. Lovenberg, and T. L. O'Donohue (1986) Characterization and autoradiographic localization of multiple tachykinin binding sites in gastrointestinal tract and bladder. J. Pharmacol. Exp. Ther. 236: 819-831.

Cascieri, M. A. and 'I. Liang (1984) Binding of [ $\left.{ }^{123} \mathrm{I}\right]$ Bolton Hunter conjugated eledoisin to rat brain cortex membranes. Evidence for two classes of tachykinin receptors in the mammalian nervous system. Life Sci. 35: 179-184.

Cascieri, M. A., G. G. Chicchi, and T. Liang (1985) Demonstration of two distinct tachykinin receptors in rat brain cortex. J. Biol. Chem. 260: 1501-1507.

Chang, M. M., and S. E. Leeman (1970) Isolation of a sialogogic peptide from bovine hypothalamic tissuc and its characterization as substance P. J. Biol. Chem. 245: 4784-4790.

Charlton, C. G., and C. J. Helke (1985) Autoradiographic localization and characterization of spinal cord substance $P$ binding sites: High densities in sensory, autonomic, phrenic and Onuf's motor nuclei. J. Neurosci. 5: 1653-1661.

Dale, H. H. (1935) Walter Ernest Dixon Memorial Lecture. Proc. R. Soc. Med. Ther. Sec. 28: 319-332.

Deacon, C. F., D. V. Agoston, R. Nau, and J. M. Conlon (1987) Conversion of neuropeptide $K$ to neurokinin $A$ and vesicular colocalization of neurokinin $A$ and substance $P$ in neurons in the guinea pig small intestine. J. Neurochem. 48: 141-146.

Eccles, J. C. (1957) The Physiology of Nerve Cells, Johns Hopkins Press, Baltimore.

Espamer, V. (1981) The tachykinin peptide family. Trends Neurosci. 4: $267-269$.

Franco, R., M. Costa, and J. B. Furness (1979) Evidence for the release of endogenous substance P from intestinal nerves. Naunyn-Schmiedeberg's Arch. Pharmacol. 301: 195-202.

Harada, Y., T. Takahashi, M. Kuno, K. Nakayama, Y. Masu, and S. Nakanishi (1987) Expression of two different tachykinin receptors in Xenopus oocytes by exogenous mRNAs. J. Neurosci. 7: 3265-3273.

Harmar, A. J., A. Armstrong, J. C. Pascall, K. Chapman, R. Rosie, A. 
Curtis, J. Going, C. R. W. Edwards, and G. Fink (1986) cDNA sequence of human B-preprotachykinin, the common precursor to substance $P$ and neurokinin A. FEBS 208: 67-72.

Helke, C. J., C. W. Shultz, T. N. Chase, and T. L. O'Donohue (1984) Autoradiographic localization of substance $P$ receptors in rat medulla: Effect of vagotomy and nodose ganglionectomy. Neuroscience 12: $215-223$.

Henry, J. L., R. Couture, A. C. Cuello, G. Pelletier, R. Quirion, D. Regoli, eds. (1987) Substance $P$ and Neurokinins, Springer-Verlag, New York.

Herkenham, M., and C. B. Pert (1982) Light microscopic localization of brain opiate receptors: A general autoradiographic method which preserves tissue quality. J. Neurosci. 2: 1129-1149.

Herkenham, M., and L. Sokoloff (1984) Quantitative receptor autoradiography: Tissue defatting eliminates differental self-absorbtion of tritium radiation in grey and white matter of brain. Brain Res. 321: 363-368.

Hunter, W. M., and F. C. Greenwood (1962) Preparation of iodine131 labelled human growth hormone of high specific activity. Nature 194: 495-496.

Kanazawa, I., T. Ogawa, S. Kimura, and E. Munekata (1984) Regional distribution of substance $\mathrm{P}$, neurokinin $\alpha$ and neurokinin $\beta$ in rat central nervous system. Neurosci. Res. 2: 111-120.

Kangawa, K., N. Minamino, A. Fukuda, and H. Matsuo (1983) Neuromedin $\mathrm{K}$ : A novel mammalian tachykinin identified in porcine spinal cord. Biochem. Biophys. Res. Commun. 114: 533-540.

Kimura, S., M. Okada, Y. Sugita, and K. I. Munekata (1983) Novel neuropeptides, neurokinin $\alpha$ and neurokinin $\beta$, isolated from porcine spinal cord. Proc. Jpn. Acad. Ser. B. 59: 101-104.

Kotani, H., M. Hoshimaru, H. Nawa, and S. Nakanishi (1986) Structure and gene organization of bovine neuromedin K precursor. Proc. Natl. Acad. Sci. USA 83: 7074-7078.

Krause, J. E., J. M. Chirgwin, M. S. Carter, Z. S. Xu, and A. D. Hershey (1987) Three rat preprotachykinin mRNAs encode the neuropeptides substance $P$ and neurokinin A. Proc. Natl. Acad. Sci. USA 84: 881885.

Laufer, R., C. Gilon, M. Chorev, and Z. Selinger (1986) Characterization of a neurokinin $\mathrm{B}$ receptor site in rat brain using a highly selective radioligand. J. Biol. Chem. 261: 10257-10263.

Lee, C. M., L. L. Iversen, M. R. Hanley, and B. E. B. Sandberg (1982) The possible existence of multiple receptors for substance $P$. NaunynSchmiedeberg's Arch. Pharmacol. 318: 281-287.

Lee, C. M., N. J. Campbell, B. J. Williams, and L. L. Iversen (1986) Multiple tachykinin binding sites in peripheral tissues and brain. Eur. J. Pharmacol. 130: 209-217.

Maggio, J. E. (1985) "Kassinin" in mammals: The newest tachykinins. Peptides 6: 237-243.

Maggio, J. E. (1988) Tachykinins. Annu. Rev. Neurosci. 11: 13-28. Maggio, J. E., and J. C. Hunter (1984) Regional distribution of kassinin-like immunoreactivity in rat central and peripheral tissues and the effect of capsaicin. Brain Res. 307: 370-373.

Maggio, J. E., B. E. B. Sandberg, C. V. Bradley, L. L. Iversen, S. Santikarn, D. H. Williams, J. C. Hunter, and M. R. Hanley (1983) Substance K: A novel tachykinin in mammalian spinal cord. In $\mathrm{Sub}$ stance P-Dublin 1983, P. Skrabanek and D. Powell, eds., pp. 2021, Boole Press, Dublin.

Maggio, J. E., C. R. Mantyh, and P. W. Mantyh (1985) Tachykinin receptors in mammals. Soc. Neurosci. Abstr. 15: p415.

Mantyh, P. W., and S. P. Hunt (1986) Changes in ${ }^{3} \mathrm{H}$-substance $\mathrm{P}$ receptor binding in the rat brain after kianic lesion of the corpus striatum. J. Neurosci. 6: 1537-1544.

Mantyh, P. W., M. Goedert, and S. P. Hunt (1984a) Autoradiographic localization of receptor binding sites for substance $P$ in the gastrointestinal tract and periphery of the guinea pig. Soc. Neurosci. Abstr. 10:214.

Mantyh P. W., M. Goedert, and S. P. Hunt (1984b) Autoradiographic visualization of receptor binding sites for substance $P$ in the gastrointestinal tract of the guinea pig. Eur. J. Pharmacol. 100: 133-134.

Mantyh P. W., S. P. Hunt, and J. E. Maggio (1984c) Substance P receptors: Localization by light microscopic autoradiography in rat brain using [ $\left.{ }^{3} \mathrm{H}\right]-\mathrm{SP}$ as the radioligand. Brain Res. 307: 147-165.

Mantyh, P. W., J. E. Maggio, and S. P. Hunt (1984d) The autoradiographic distribution of kassinin and substance $\mathrm{K}$ binding sites is different from the distribution of substance $P$ binding sites in rat brain. Eur. J. Pharmacol, 102: 361-364.
Mantyh, P. W., R. D. Pinnock, C. P. Downes, M. Goedert, and S. P. Hunt (1984e) Substance $\mathbf{P}$ receptors: Correlation with substance $\mathbf{P}$ induced inositol phospholipid hydrolysis in the rat central nervous system. Nature 309: 795-797.

Mantyh, P. W., C. R. Mantyh, and J. E. Maggio (1987) Heterogeneity of tachykinin receptors. In Substance $P$ and Neurokinins, James $\mathbf{L}$. Henry, ed., pp. 366-371, Springer-Verlag, New York.

Mantyh, C. R., T. S. Gates, R. P. Zimmerman, M. L. Welton, E. P. Passaro, S. R. Vigna, J. E. Maggio, L. Kruger, and P. W. Mantyh (1988a) Receptor binding sites for substance $P$, but not substance $K$ or meuromedin $\mathrm{K}$, are expressed in high concentrations by arterioles, venules and lymph nodules in surgical specimens obtained from patients with ulcerative colitis and Crohn's disease. Proc. Natl. Acad. Sci. USA 85: 3235-3239.

Mantyh, P. W., C. R. Mantyh, T. Gates, S. R. Vigna, and J. E. Maggio (1988b) Receptor binding sites for substance $\mathbf{P}$ and substance $\mathrm{K}$ in the canine gastrointestinal tract and their possible role in inflammatory bowel disease. Neuroscience 3: 817-837.

Masu, Y., K. Nakayama, H. Tamaki, Y. Harada, M. Kuno, and S. Nakanishi (1987) cDNA cloning of bovine substance-K receptor through oocyte expression system. Nature 329: 836-838.

Melchiorri, P., and L. Negri (1984) Evolutionary aspects of amphibian peptides. In Evolution and Tumor Pathology of the Neuroendocrine System, S. Falkmer, R. Hakason, and S. Sundler, eds., pp. 231-244, Elsevier, Amersham, UK.

Minamino, N., H. Masuda, K. Kangawa, and H. Matsuo (1984) Regional distribution of neuromedin $\mathrm{K}$ and neuromedin $\mathrm{L}$ in rat brain and spinal cord. Biochem. Biophys. Res. Commun. 124: 731-738.

Nawa, H., T. Hirose, H. Takashima, S. Inayama, and S. Nakanishi (1983) Nucleotide sequences of cloned cDNAs for two types of bovine brain substance $P$ precursor. Nature 306: 32-36.

Nawa, H., H. Kotani, and S. Nakanishi (1984) Tissue-specific generation of two preprotachykinin mRNAs from one gene by alternative mRNA splicing. Nature 312: 729-734.

Nilsson, G., L. I. Larsson, R. Hakanson, E. Brodin, B. Pernow, and F. Sundler (1975) Localization of substance P-like immunoreactivity in the mouse gut. Histochemistry 43: 97-99.

Ninkovic, M., J. C. Beaujouan, Y. Torrens, M. Saffroy, M. D. Hall, and J. Glowinski (1984) Differential localization of tachykinin receptors in rat spinal cord. Eur. J. Pharmacol. 106: 463-464.

Ogawa, T., I. Kanazawa, and S. Kimura (1985) Regional distribution of substance $P$, neurokinin and neurokinin in rat spinal cord, nerve roots and dorsal root ganglia and the effects of dorsal root section or spinal transsection. Brain Res. 359: 152-157.

Paxinos, G., and C. Watson (1982) The Rat Brain in Stereotaxic Coordinates, Academic, New York.

Pernow, B. (1983) Substance P. Pharmacol. Rev. 35: 85-141.

Piercey, M. F., P. J. K. Dobry-Scheur, N. Masiques, and L. A. Schroeder (1985) Sterospecificity of SP1 and SP2, substance P receptors. Life Sci. 36: 777-780.

Quirion, R., and C. Pilapil (1984) Comparative potencies of substance $P$, substance $K$ and neuromedin $K$ on brain substance $P$ receptors. Neuropeptides 4: 325-329.

Quirion, R., C. W. Schults, T. W. Moody, C. B. Pert, T. N. Chase, and T. L. O'Donohue (1983) Autoradiographic distribution of substance $P$ receptors in rat central nervous gystem. Naturc 303: 714-716.

Rainbow, T. C., A. Biegon, and D. J. Berck (1984) Quantitative receptor autoradiography with tritium-labeled ligands: Comparison of biochemical and densitometric measurements. J. Neurosci. Methods. 11: 231-241.

Regoli, D., P. D’Orleans, G. Drapeau, S. Dion, and E. Escher (1985) Pharmacological characterization of substance $P$ antagonists. In Tachykinin Antagonists, R. Hakanson and F. Sundler, eds., Elsevier, Amsterdam.

Rothman, R. B., J. A. Danks, M. Herkenham, M. A. Cascieri, G. G. Chicchi, T. Liang, and C. B. Pert (1984a) Autoradiographic localization of novel peptide binding sites in rat brain using the substance $P$ analog, eledoisin. Neuropeptides 4: 343-349.

Rothman, R. B., M. Herkenham, C. B. Pert, T. Liang, and M. A. Cacieri (1984b) Visualization of ral brain receptors for the neuropeptide, substance P. Brain Res. 309: 47-54.

Shults, C. W., R. Quirion, R. T. Jensen, T. W. Moody, T. L. O'Donohue, and T. L. Chase (1982) Autoradiographic localization of substance $P$ receptors using [ $\left.{ }^{125} I\right]$ substance $P$. Peptides 3: 1073-1075.

Shults, C. W., R. Quirion, B. Chronwell, T. N. Chase, and T. O'Donohue 
(1984) A comparison of the anatomical distribution of substance $P$ and substance $P$ rcecptors in the rat central nervous system. Peptides 5: $1097-1128$.

Shults, C. W., P. Johnston, and J. Bressler (1987) Characterization of substance $P$ receptor on cultured rat astrocytes. Soc. Neurosci. Abstr. p413.

Souquet, J. C., J. R. Grider, K. N. Bitar, and G. M. Makhlouf (1985) Receptors for mammalian tachykinins on isolated intestinal smooth muscle cells. Am. J. Physiol. G533-538.

Torrens, Y., J. C. Beaujouan, A. Viger, and J. Glowinski (1983) Properties of a [ $\left.{ }^{125} I\right]$ substance $P$ derivative binding to synaptosome from various brain structures and the spinal cord of the rat. NaunynSchmicdebergs Arch. Pharmacol. 324: 134-139.

Torrens, Y., S. Lavielle, G. Chaissaing, A. Marquet, J. Glowinski, and J. C. Beaujouan (1984) Neuromedin K, a tool to further distinguish two central tachykinin binding sites. Eur. J. Pharmacol. 102: 381382.
Torrens, Y., J. C. Beaujouan, and J. Glowinski (1985) Pharmacological characterization of two tachykinin binding sites in the rat cerebral cortex. Neuropeptides 6: 59-70.

Torrens, Y., J. C. Beaujouan, M. Saffroy, M. C. Daguet de Montety, L. Bergstrom, and J. Glowinski (1986) Substance P receptors in primary cultures of cortical astrocytes from the mouse. Proc. Natl. Acad. Sci. USA 83: 9216-9220.

Viger, A., J. C. Beaujouan, Y. Torrens, and J. Glowinski (1983) Specific binding of a [ $\left.{ }^{125} \mathrm{I}\right]$ substance $\mathrm{P}$ derivative to rat brain synaptosomes. J. Neurochem. 40:1030-1039.

Zimmerman, R. P., T. S. Gates, C. G. Boehmer, D. J. Johnson, and P. W. Mantyh (1988) In-situ demonstration that substance $P$ receptors are expressed by glia after neuronal injury. Soc. Neurosci. Abstr. (in press). 